NBER WORKING PAPER SERIES

\title{
THE EFFECT OF WEALTH ON INDIVIDUAL AND HOUSEHOLD LABOR SUPPLY: EVIDENCE FROM SWEDISH LOTTERIES
}

\author{
David Cesarini \\ Erik Lindqvist \\ Matthew J. Notowidigdo \\ Robert Östling \\ Working Paper 21762 \\ http://www.nber.org/papers/w21762 \\ NATIONAL BUREAU OF ECONOMIC RESEARCH \\ 1050 Massachusetts Avenue \\ Cambridge, MA 02138 \\ November 2015
}

We thank Pierre-André Chiappori, David Domeij, Trevor Gallen, Erik Hurst, Che-Yuan Liang, Jonna Olsson, Jesse Shapiro, Johanna Wallenius, and seminar audiences at the AEA Annual Meeting, Bocconi, Chicago Booth, Cornell University, LSE, CREI-UPF, NBER Summer Institute, Northwestern University, the Rady School of Management, Stockholm University, and Uppsala University for helpful comments. We also thank Richard Foltyn, Renjie Jiang, Kristztian Kovacs, Odd Lyssarides, Svante Midander, and Erik Tengbjörk for excellent research assistance. This paper is part of a project hosted by the Research Institute of Industrial Economics (IFN). We are grateful to IFN Director Magnus Henrekson for his strong commitment to the project and to Marta Benkestock for superb administrative assistance. The project is financially supported by three large grants from the Swedish Research Council (B0213903), Handelsbanken's Research Foundations (P2011:0032:1) and the Bank of Sweden Tercentenary Foundation (P15-0615:1). We also gratefully acknowledge financial support from the NBER Household Finance working group (22-2382-13-1-33-003), the NSF (1326635), and the Swedish Council for Working Life and Social Research (2011-1437). The views expressed herein are those of the authors and do not necessarily reflect the views of the National Bureau of Economic Research.

NBER working papers are circulated for discussion and comment purposes. They have not been peerreviewed or been subject to the review by the NBER Board of Directors that accompanies official NBER publications.

(C) 2015 by David Cesarini, Erik Lindqvist, Matthew J. Notowidigdo, and Robert Östling. All rights reserved. Short sections of text, not to exceed two paragraphs, may be quoted without explicit permission provided that full credit, including $\odot$ notice, is given to the source. 
The Effect of Wealth on Individual and Household Labor Supply: Evidence from Swedish

Lotteries

David Cesarini, Erik Lindqvist, Matthew J. Notowidigdo, and Robert Östling

NBER Working Paper No. 21762

November 2015

JEL No. J22,J26

\section{ABSTRACT}

We study the effect of wealth on labor supply using the randomized assignment of monetary prizes in a large sample of Swedish lottery players. We find winning a lottery prize modestly reduces labor earnings, with the reduction being immediate, persistent, and similar by age, education, and sex. A calibrated dynamic model of individual labor supply implies an average lifetime marginal propensity to earn out of unearned income of -0.11 , and labor-supply elasticities in the lower range of previously reported estimates. The earnings response is stronger for winners than their spouses, which is inconsistent with unitary household labor supply models.

\author{
David Cesarini \\ Department of Economics \\ New York University \\ 19 West 4th Street, Room 511 \\ New York, NY 10012 \\ and NBER \\ dac12@nyu.edu \\ Erik Lindqvist \\ Stockholm School of Economics \\ Box 6501 \\ SE-113 83 Stockholm \\ SWEDEN \\ erik.lindqvist@hhs.se
}

\author{
Matthew J. Notowidigdo \\ Northwestern University \\ Department of Economics \\ 2001 Sheridan Road \\ Evanston, IL 60208-2600 \\ and NBER \\ noto@northwestern.edu \\ Robert Östling \\ Stockholm University \\ Institute for International Economic Studies \\ 10691 Stockholm \\ Sweden \\ robert.ostling@iies.su.se
}

Supplementary materials available at http://www.nber.org/papers/w21762:

- Online Appendix 
Understanding how labor supply responds to changes in wealth is critical when evaluating many economic policies, such as changes to retirement systems, property taxes, and lump-sum components of welfare payments. Because the income effect provides the link between uncompensated and compensated wage elasticities via the Slutsky equation, accurate estimates of how labor supply responds to wealth shocks are also valuable for obtaining credible estimates of compensated wage elasticities (Keane, 2011), which, in turn, are critical inputs in the theory of taxation (Mirrlees, 1971; Saez, 2001) and studies of business cycle fluctuations (Prescott, 1986; Rebelo, 2005).

Despite a large empirical literature, consensus on the magnitude of the effect of wealth on labor supply is limited (Pencavel, 1986; Blundell and MaCurdy, 2000; Keane, 2011; Saez et al., 2012). Although some agreement exists among labor economists that large, permanent changes in real wages induce relatively modest differences in labor supply, Kimball and Shapiro (2008) write that "there is much less agreement about whether the income and substitution effects are both large or both small.” The lack of consensus stems in part from the substantial practical challenges associated with isolating plausibly exogenous variation in unearned income or wealth, which is necessary to produce credible wealth effect estimates. In this paper, we confront these challenges by exploiting the randomized assignment of lottery prizes to estimate the causal impact of wealth on individual- and household-level labor supply. Our work is most closely related to Imbens, Rubin, and Sacerdote's (2001) survey of Massachusetts Lottery players. ${ }^{1}$ Comparing winners of large and small prizes who gave consent to release their post-lottery earnings data from tax records, they estimate that around $11 \%$ of an exogenous increase in unearned income is spent on reducing labor earnings.

Our study has three key methodological features that enable us to make stronger inferences about the causal impact of wealth than previous lottery studies evaluating the effect of wealth on labor supply (Kaplan, 1985; Imbens et al., 2001; Arvey and Liao, 2004; Furåker and Hedenus, 2009;

\footnotetext{
${ }^{1}$ Our work is also related to previous research that uses natural experiments such as policy changes or bequests to estimate the causal effect of wealth on labor supply (Bodkin, 1959; Krueger and Pischke, 1992; Holtz-Eakin et al., 1993; Joulfaian and Wilhelm, 1994).
} 
Hedenus, 2009; Larsson, 2011; Picchio et al., 2015). First, we observe the factors conditional on which the lottery wealth is randomly assigned, allowing us to leverage only the portion of lotteryinduced variation in wealth that is exogenous. Second, the size of the prize pool is very large (approximately $\$ 650$ million), allowing us to obtain precise estimates of treatment effects in many subsamples. Prizes also vary in magnitude, which allows us to test for nonlinear effects. ${ }^{2}$ Third, Sweden's high-quality administrative data allow us to observe a rich set of labor market outcomes many years after the event, in a virtually attrition-free sample. Finally, our data allow us to address many (but not all) concerns that are often voiced about the external validity of studies of lottery players.

In our reduced-form analyses of individual-level labor supply, we find winning a lottery prize immediately reduces labor earnings, with effects roughly constant over time and lasting more than 10 years. In our main specification, a windfall gain of 1 million Swedish krona (about $\$ 140,000$ ) reduces the pre-tax labor earnings of the winner over the first 10 years by roughly 80,000 SEK, or approximately one half of the average annual income. A reduction in hours worked accounts for the majority of the overall earnings response. Evidence of heterogeneous or nonlinear effects is scant, and winners are not more likely to change employers, industries or occupations. We also find winning a lottery prize reduces self-employment income as well as the probability of being self-employed, which contrasts with several studies finding that positive wealth shocks increase transition into self-employment (Holtz-Eakin et al., 1994; Lindh and Ohlsson, 1996; Taylor, 2001; Andersen and Nielsen, 2012).

A simple dynamic labor supply model with a binding retirement age can qualitatively and quantitatively account for our main reduced-form results. Models without retirement predict laborearnings responses that vary strongly with age (see, e.g., Imbens et al., 2001), a prediction our reduced-form estimates do not bear out. Including a binding retirement age attenuates the rela-

\footnotetext{
${ }^{2}$ The estimated effects in Imbens et al. (2001) are highly non-linear and also somewhat sensitive to the small number of individuals in the sample who won prizes exceeding \$2 million USD, as well as specifications that account for non-random survey non-response (Hirano and Imbens, 2004).
} 
tionship between the lottery-induced labor earnings reduction and age, and allows our simulated model to more closely match the reduced-form empirical results. We account for the role of taxes by calibrating the model to match the after-tax earnings response.

We use the calibrated model to extend the results well beyond the first 10 years following the prize event to estimate lifetime marginal propensities to earn income (MPE) out of lottery wealth. The simulation results indicate the lifetime wealth effect would be understated substantially if only the first 10 years were included. We also show the best-fit parameters imply the lifetime MPE varies with age and is strongest in the youngest winners, where our estimates suggest a lifetime MPE in the range -0.15 to -0.19 . We also use the full structure of the model to estimate key labor-supply elasticities. The average uncompensated labor supply elasticity is close to zero, the individual-level compensated (Hicksian) elasticity is 0.1 and the intertemporal (Frisch) elasticity is 0.2. These estimates are in the lower range of previously reported estimates (Keane, 2011; Reichling and Whalen, 2012).

In our household-level analyses, we find that taking into account the labor supply of non-winning spouses increases the estimated effect on earnings by $24 \%$. Our estimates are precise enough to reject both a zero effect on the non-winning spouse's earnings and the null hypothesis that the earnings responses of winning and non-winnning spouses are identical; we systematically find the winning spouse reacts more strongly. The latter result is inconsistent with unitary household labor supply models, which have the strong prediction that the observed labor supply responses to household wealth shocks should not depend on the identity of the lottery winner (Kimball and Shapiro, 2008; Blundell et al., 2014).

Our finding that winners adjust labor supply more strongly than spouses complements a large empirical literature (see the review by Chiappori and Donni, 2009) that uses labor supply data to test the exogenous income pooling restriction of unitary models of the household. As described in Lundberg and Pollak (1996, p. 145), an "ideal test of the pooling hypothesis would be based on an experiment in which some husbands and some wives were randomly selected to receive an 
income transfer." Our test comes close to these ideal conditions, and to our knowledge, we are the first to use random shocks to wealth from lottery prizes to both husbands and wives to directly test whether income is pooled when households make labor supply decisions.

The remainder of this paper is structured as follows. Section I describes the lottery data and our measures of labor supply. Section II discusses our empirical framework and reports the results from a randomization test. Section III reports our main individual-level empirical results. Section IV describes a dynamic life-cycle model, shows this model can quantitatively account for our main results, and uses this model to estimate key labor supply elasticities. Section V reports householdlevel results and discusses how they inform household labor supply models. Section VI concludes the paper. In the interest of brevity, we refer the interested reader to our Online Appendix (hereafter, "OA") for a number of robustness tests and details regarding our measures of labor supply and the institutional background. Tables and figures prefaced by the letter "A" are included in the OA.

\section{Data}

We construct our estimation sample by matching three samples of lottery players and their spouses to population-based registers on labor market outcomes and demographic characteristics. We first describe the key variables obtained from population-based registers that we use throughout our analyses.

\section{A. Outcome Variables}

All earnings measures are based on population-wide registers originally collected by the tax authorities. Throughout the paper, we convert monetary variables to year-2010 SEK and all dollar amounts cited are converted using the January 2010 exchange rate (\$7.1534 per SEK). Detailed variable definitions are relegated to section 4 in the OA.

Sweden underwent a major tax reform in 1990-1991. Before 1991, capital and labor incomes were taxed jointly and taxes were strongly progressive, which complicates the analysis of wealth 
effects. We therefore restrict attention to labor supply in 1991-2010 when labor earnings and capital income are taxed separately.

Pre-tax Labor Earnings. Our main outcome variable is annual gross labor earnings. This income measure includes wage income, income from self-employment, and income support during sickness absence and parental leave, while unemployment support and pension income are excluded. We also study the two key components of labor earnings separately: wage earnings and self-employment income.

After-tax Earnings. We compute after-tax income using detailed information about the Swedish tax system; see OA section 4.2 for details. Because labor earnings, pension income, and unemployment benefits are all taxed jointly, we calculate after-tax income using overall taxable income, which includes both pension income and unemployment benefits. Employers pay social security contributions (SSC) on top of gross earnings. SSC is partly a tax on labor and partly tied to future benefits, and we adjust the earnings measures accordingly in some of our analyses. In OA section 10 , we discuss the robustness to an alternative after-tax income measure.

Wages and Hours Worked. We supplement the register-based variables with information about wages and hours worked obtained from Statistics Sweden's annual wage survey. The survey has incomplete coverage for the private sector, and in any given year, it covers about $60 \%$ of the people in our sample who are working (see Figure A4.4). To increase coverage, we impute wages from adjacent years, but we do not use observations from the post-win period to impute wages from the pre-win period, or vice versa. The wage data allow us to calculate hours worked as the ratio of wage earnings and wages. We express hours worked in percent of full-time work and censor at $125 \%$ of full-time. ${ }^{3}$

Employer and Occupation Switching. The wage survey also includes data on occupation, which we use to estimate the effect of wealth on occupation switching. To examine whether wealth

\footnotetext{
${ }^{3}$ We censor hours worked to reduce the problem of outliers due to division bias (downward bias in wages causing an upward bias in hours worked). The wage survey also includes a direct measure of hours worked. In OA section 11, we show the results are similar if we use this alternative measure.
} 
affects the choice of employer, workplace, industry, and the geographical location of work, we use data from Statistics Sweden's registry of employers.

\section{B. Lottery Samples}

We use data from three different lotteries. For each lottery, we use available data and knowledge about the institutional details to define "cells" within which the lottery wealth is randomly assigned. Controlling for cell fixed effects in our analyses ensures all identifying variation comes from players in the same cell. Because the exact construction of the cells varies across lotteries, we describe each lottery separately. ${ }^{4}$ The lottery cell construction is summarized in Table A3.1. Throughout the paper, we restrict attention to players who were between age 21 and 64 at the time of the win. All prizes are net of taxes.

Prize-Linked Savings Accounts. The first sample we use is a panel of Swedish individuals who held "prize-linked savings" (PLS) accounts between 1986 and 2003. PLS accounts incorporate a lottery element by randomly awarding prizes to some accounts rather than paying interest (Kearney et al., 2011). PLS accounts have existed in Sweden since 1949 and were originally subsidized by the government. When the subsidies ceased in 1985, the government authorized banks to continue to offer prize-linked-savings products. Two systems were put into place, one operated by savings banks and one by the major commercial banks and the state bank. Each system had over 2 million accounts in the late 1980s, implying that half of the Swedish population held a PLS account at the time.

We combine two sources of information from the PLS program run by the commercial banks, Vinnarkontot ("The Winner Account"). Our first source is a set of prize lists with information about all prizes won in the draws between 1986 and 2003. The prize lists were entered manually and contain information about prize amount, prize type (described below), and the winning account

\footnotetext{
${ }^{4} \mathrm{~A}$ detailed account of the institutional features of our three lottery samples, the processing of our primary sources of lottery data, data quality, and how cells were constructed is provided in the Online Appendix to Cesarini et al. (2015).
} 
number, but not the identity of the winner. The second source is a large number of microfiche images with information about account number, the account owner's personal identification number (PIN), and the account balance of all eligible accounts participating in the draws between December 1986 and December 1994 (the "fiche period"). ${ }^{5}$ By matching the prize-list data with the microfiche data, we are able to identify PLS winners between 1986 and 2003 who held an account during the fiche period.

PLS account holders could win two types of prizes: odds prizes and fixed prizes. The probability of winning either type of prize was proportional to the number of tickets associated with an account: account holders assigned one lottery ticket per 100 SEK in the account balance. Fixed prizes were prizes whose magnitude did not depend on the balance of the winning account. Odds prizes, on the other hand, paid a multiple of 1,10 , or 100 times the account balance to the winner (with the prize capped at 1 million SEK).

For fixed-prize winners, our identification strategy exploits the fact that in the population of players who won the same number of fixed prizes in a particular month, the actual prize amount is independent of account balances (and therefore potential outcomes). For each draw, we define cells comprising all individuals who won the same number of prizes in the draw. We hence exclude account holders that never won from the sample.

To construct odds-prize cells, we match individuals who won exactly one odds prize in a draw to individuals who also won exactly one prize (odds or fixed) in the same draw and whose account balance is nearly identical to the winner. This matching procedure ensures that within a cell, the prize amount is independent of potential outcomes. To avoid double-counting, a fixed-prize winner who is successfully matched to an odds-prize winner is assigned to the new odds-prize cell instead of the original fixed-prize cell. We do not observe account balances after 1994; therefore, we restrict attention to odds prizes won during the fiche period (1986 to 1994). To keep the number of

\footnotetext{
${ }^{5}$ The Online Appendix to Cesarini et al. (2015) provides a detailed account of how the microfiche images were digitized and processed to construct a monthly panel for the years 1986-1994.
} 
cells manageable, we exclude all odds prizes below 100,000 SEK.

The Kombi Lottery. Our second sample is an unbalanced panel of about half a million individuals who participated in a monthly ticket-subscription lottery called Kombilotteriet (“Kombi”). The proceeds from Kombi go to the Swedish Social Democratic Party, Sweden's main political party during the post-war era. Subscribers choose their desired number of subscription tickets and are billed monthly. Our data set contains information about all draws conducted between 1998 and 2010. For each subscriber, the data contains information about the number of tickets held in each draw and information about prizes exceeding 1M SEK. The Kombi rules are simple: two individuals who purchased the same number of tickets in a given draw face the same probability of winning a large prize. To construct the cells, we match each winning player to (up to) 100 non-winning players with an identical number of tickets in the month of the draw. To improve the precision of our estimates, we choose controls of the same sex and similar age whenever more than 100 matches are available.

The Triss Lottery. Triss is a scratch-ticket lottery run since 1986 by Svenska Spel, the Swedish government-owned gaming operator. Triss lottery tickets can be bought in virtually any Swedish store. The sample we have access to consists of two categories of winners: Triss-Lumpsum and Triss-Monthly. Winners of either type of prize are invited to participate in a morning TV show. At the show, Triss-Lumpsum winners draw a new scratch-off ticket from a stack of tickets with a known prize plan that is subject to occasional revision. Triss-Lumpsum prizes vary in size from 50,000 to 5 million SEK. Triss-Monthly winners participate in the same TV show, but draw one ticket that determines the size of a monthly installment and a second that determines its duration. The tickets are drawn independently. The durations range from 10 to 50 years, and the monthly installments range from 10,000 to 50,000 SEK. To make the monthly installments in Triss-Monthly comparable to the lump-sum prizes in the other lotteries, we convert them to present value using a $2 \%$ annual discount rate. ${ }^{6}$ We exclude about $10 \%$ of the lottery prizes for which the data indicate

${ }^{6}$ We set the discount rate to match the real interest rate in Sweden, which, according to Lagerwall (2008), was $1.9 \%$ during 1958 - 
the player shared ownership of the ticket.

Conditional on the prize plan and winning the same number of prizes, the nominal prize amount is random in both Triss-Lumpsum and Triss-Monthly. We therefore assign players to the same cell if they won exactly one prize (of the same type) in the same year and under the same prize plan.

\section{Prize Distribution}

Table 1 shows the distribution of prizes in the pooled sample and for each lottery separately. In total, there are more than 5,500 prizes in excess of 100,000 SEK $(\$ 14,000)$ and almost 1,500 prizes of 1 million SEK $(\$ 140,000)$ or more. To put these numbers into perspective, the median disposable income among a representative sample of Swedes in 2000 was 170,000 SEK. The total prize amount in our pooled sample is 4,662 million SEK (about $\$ 650$ million). Although the number of winners is much larger in PLS, PLS prizes only constitute $36 \%$ of the total prize amount. ${ }^{7}$

\section{[TABLE 1 HERE]}

\section{Representativeness}

An important concern about lottery studies is that they may lack external validity because lottery players are not representative of the general population. Table A3.2 therefore provides information about the demographic characteristics of players in each of our lottery samples. To evaluate the representativeness of the lottery samples, we also report descriptive statistics for random population samples drawn in 1990 and 2000. We reweight the representative samples to match the age and sex distribution of the lottery winners. Overall, the results from this comparison suggest that, at least in terms of observable characteristics, we find no large differences between the players we study and a representative sample of the Swedish population. Figure A2.1 displays the age distribution at the time of the win for the pooled sample (average age $=48.6$ ).

2008.

${ }^{7}$ Triss-Monthly makes up 36\% of the total prize amount; Triss-Lumpsum, $21 \%$; and Kombi, $7 \%$. 
A related concern is that, even though lottery players may be similar to the population at large, lottery prizes constitute a specific type of wealth shock that cannot be generalized to other types of wealth. Although we cannot rule out this concern completely, the evidence presented below shows lottery winners do not squander their wealth, and their labor supply response fits the predictions of standard life-cycle models fairly well irrespective of the type of lottery (PLS, Kombi or Triss) or mode of payment (Triss-Lumpsum or Triss-Monthly).

\section{Identification Strategy}

Controlling for cell fixed effects in our analyses ensures all identifying variation comes from players in the same cell. If the identifying assumptions underlying the lottery cell construction are correct, then characteristics determined before the lottery should not predict the amount won once we condition on cell fixed effects. To test for violation of conditional random assignment, we therefore run the regression

$$
L_{i, 0}=\mathbf{X}_{i} \boldsymbol{\eta}+\mathbf{Z}_{i,-1} \boldsymbol{\theta}+\epsilon_{i, 0}
$$

where $L_{i, 0}$ is the prize money at the time of the event, $\mathbf{X}_{i}$ is a vector of cell fixed effects, and $\mathbf{Z}_{-1}$ is a vector of baseline controls that includes indicator variables for sex, region of birth, and college completion, as well as labor earnings and a third-order polynomial in age in the year before the lottery. The time-varying baseline covariates are measured in the year prior to the lottery. Table A3.3 reports the $p$-values for the individual and joint significance of the baseline controls in the pooled sample and for each lottery separately. For the pooled sample, we also estimate the equation without cell fixed effects. Overall, the results are consistent with the null hypothesis that wealth is randomly assigned once we condition on the cell fixed effects. 
Normalizing the time of the lottery to $t=0$, our basic estimating equation is

$$
y_{i, t}=\beta_{t} L_{i, 0}+\mathbf{X}_{i} \boldsymbol{\delta}_{t}+\mathbf{Z}_{i,-1} \gamma_{t}+\varepsilon_{i, t} \quad(t=0,1, \ldots T),
$$

where $y_{i, t}$ is individual $i$ 's outcome of interest at time $t$, and $L_{i, 0}$ and $\mathbf{X}_{i}$ are defined exactly as in the previous section. The controls for pre-lottery characteristics, $\mathbf{Z}_{i,-1}$, are included only to increase the precision of our estimated treatment effects. In our preferred specification, $\mathbf{Z}_{i,-1}$ includes the same controls as in the randomization tests in Table A3.3, as well as the lagged value of the dependent variable measured in year $t=-1$ whenever it is available. We use OLS to estimate equation (2) and cluster standard errors at the level of the individual.

The key estimated coefficients $\hat{\beta}_{0}, \hat{\beta}_{1}, \ldots, \hat{\beta}_{10}$ flexibly capture the dynamic effect of a wealth shock at time $t=0 .{ }^{8}$ We also consider an event-study framework and impose the restriction that $\beta_{t}=\beta$ for all $t=1, \ldots, 5 .^{9}$ The event-study estimates increase statistical power and allow us to present our findings in a more parsimonious way. Because we restrict the sample to individuals aged 21-64 at the time of winning, some of our winners reach retirement age over the time horizon we consider. Rather than restricting the basic estimation sample, we incorporate a binding retirement age in the dynamic labor supply model used to interpret the reduced-form results. We also show reduced-form results stratified by age.

Because small average effects could mask large effects in certain subpopulations, we also test for heterogenous effects. In these analyses, we interact the lottery prize, $L_{i, 0}$, the vector of cell fixed effects, $\mathbf{X}_{i}$, and the controls, $\mathbf{Z}_{i,-1}$, with the subpopulation indicator variable of interest, thereby leveraging only within-cell variation to estimate treatment-effect heterogeneity.

\footnotetext{
${ }^{8}$ Because $y_{i, t}$ in most of our analyses are measured in 1991-2010 and the sample consists of individuals who won the lottery in 1986-2010, the composition of the pooled sample changes somewhat with $t$. For example, an individual who won the lottery in 1986 will not enter the data until $t=5$. Conversely, an individual who won in, say, 2010 will exit the data at $t=1$. In OA section 8 , we therefore also estimate equation (2) for different time horizons holding the sample fixed.

${ }^{9}$ Because the average winner will receive the prize by approximately the end of June in $t=0$, the labor supply response in $t=0$ will be about half as large as the response in $t=1$, even if individuals face no obstacle to adjusting their labor supply. We therefore exclude $t=0$ from the event-study estimates.
} 


\section{Individual-level Analyses}

We first analyze how lottery wealth affects individual labor supply. Unless otherwise stated, the outcome variable is gross labor earnings. Table 2 reports the estimated effect of wealth on gross labor earnings one and two years after the lottery, as well as the 3-, 5-, and 10-year totals. Table 2 also shows the event-study estimate for the $t=1, \ldots, 5$ horizon. Figure 1 graphically depicts the coefficient estimates, along with $95 \%$ confidence intervals, for the first 10 years after the lottery event, and the five years prior to the lottery. ${ }^{10}$ Reassuringly, Figure 1 confirms that no statistically significant difference exists in the pre-event trends of winners and non-winners. In the year of the lottery event, labor earnings decline immediately and stabilize at a level roughly 1,150 SEK lower for each 100,000 SEK won. ${ }^{11}$ We find a slight tendency of a smaller effect with time from the lottery and the 10-year reduction in earnings is 8,033 SEK per 100,000 SEK won. As our heterogeneity analyses below show, the attenuation of the response is largely due to more lottery winners reaching retirement age with time from the lottery.

[FIGURE 1 HERE]

[TABLE 2 HERE]

To give a more detailed picture of the labor supply response, Table 3 shows the event-study estimates for different earnings measures, with the event-study estimate for gross labor earnings (1.068) reported in column 1 as a benchmark. First, columns 3 and 4 show the bulk of the reduction in gross labor earnings is due to a fall in wage earnings (-0.967), but the drop in self-employment income (-0.142) is also statistically significant.

\footnotetext{
${ }^{10}$ Because Figure 1 also includes the estimated "effect" of a future lottery prize on earnings, these regressions do not include controls for time-varying characteristics (lagged labor earnings and educational attainment).

${ }^{11}$ The slight discrepancy between the estimates in Table 2 and Figure 1 is due to us conditioning on labor earnings in $t=-1$ in Table 2 but not in Figure 1. In OA section 8, we also report and discuss results for up to 20 years after the lottery. Although the overall response is reasonably stable over time, the response is larger for younger winners. The estimated effect for winners below age 45 at $t=20(-2,500$ SEK per 100,000 SEK won) implies a stronger response than we estimate in the sample at large. Due to the limited statistical power, we chose not to emphasize the long-run results, but instead rely on the model to extrapolate the long-run effect. However, the strong long-run response of young winners is a caveat to the general conclusion of modest wealth effects.
} 
Second, Table 3 shows how lottery wealth affects earnings before and after taxes. As shown in columns 5 and 6, both unemployment benefits (0.035) and earnings from the pension system (0.157) increase following a lottery win, even though only the latter effect is statistically significant. Winners are thus able to compensate part of the reduction in labor earnings by increased benefits. Because taxable earnings include both unemployment benefits and pensions, the effect on taxable earnings in column $7(-0.900)$ is smaller than the effect on gross labor earnings in column

1. Column 8 shows the effect on earnings after taxes is quite small (-0.580), reflecting both the relatively high taxes in Sweden and the increase in received benefits. When we include the value of future benefits (notably pensions) implicit in social security contributions (SSC) in our after-tax earnings measure (shown in column 9), the estimated effect is only somewhat larger (-0.624).

Finally, column 2 in Table 3 shows that adding the full amount of SSC to labor earnings increases the negative effect of wealth shocks (-1.412). Because labor earnings plus SSC represent employers' total cost of labor, the estimate in column 2 can be thought of as the effect of wealth shocks on production value. The difference between the estimates in column 2 and 8 thus reflect the wedge induced by the tax and transfer system: a net wealth shock of 100,000 SEK reduces the yearly post-win production value by approximately 1,400 SEK, whereas winners' net earnings only go down by about 600 SEK.

\section{[TABLE 3 HERE]}

To assess how important the detailed lottery data underlying the cell construction are for our identification strategy, we also provide "naïve panel study" estimates that only exploit withinindividual variation in the size and timing of lottery prizes. The results are presented in detail in OA section 12 and show the naïve estimates are approximately 50\% larger than the baseline lottery estimates. 


\section{A. Margins of Adjustment}

Table 4 shows the event-study estimates for several extensive-margin earnings measures. Winning $1 \mathrm{M}$ SEK reduces the probability of participation, defined as having labor earnings in excess of 25,000 SEK, by 2.07 percentage points. Panel A of Figure 2 shows the extensive-margin effect is strongest two years after the win, and then weakens with time. We see a similar response on the extensive margin for wage earnings $(-2.24)$ and also a reduction on the extensive margin of self-employment (-0.62).

[TABLE 4 HERE]

The estimated effects for the extensive margin implies much of the labor-supply response occurs on the intensive margin, in the form of lower wages or fewer hours. Under the assumption that the average earnings of the workers who leave the labor force equal the sample average, the extensive margin accounts for about $50 \%$ of the labor supply response immediately after winning the lottery and about one third six years after the lottery (see Panel B in Figure 2).

For the subsample for which we observe wages, we can also study the effect on wages and hours worked. Table 4 shows wages fall by 0.16 SEK per 1000 SEK won $(p=0.063)$, suggesting that the intensive-margin response partly reflects a decline in wages (see also Panel C in Figure 2). The hours response is also negative: a $1 \mathrm{M}$ SEK prize reduces hours worked by $3.11 \%$ of full-time, corresponding to 1.3 hours per week, or 60 hours per year. As shown by Panel D in Figure 2, the hours response is stable over time. Panel E in Figure 2 decomposes the total wageearnings response into hours worked and wages (see OA section 11 for details), and shows the hours response always dominates. Finally, Panel F in Figure 2 shows intensive-margin adjustments account for more than half of the hours response.

[FIGURE 2 HERE] 
In sum, adjustment takes place both along the extensive and intensive margin, with the intensive margin becoming more important with time from the lottery. The intensive-margin response is primarily due to fewer hours worked rather than a decline in wages.

Finally, we analyze whether lottery winners adjust their labor supply by changing employers, workplaces, occupations, industries, or the location of work. As Figure A2.2 shows, we find no evidence of an effect on any of these outcomes.

\section{B. Robustness and Heterogenous Effects}

We conduct a number of analyses to explore the robustness of the estimated effect on labor earnings and whether the effect differs across subgroups. We first explore whether the wealth effect is nonlinear, as would be the case if workers who wish to reduce their labor supply face fixed adjustment costs (as in Chetty et al., 2011). Table A3.4 reports the estimates from a quadratic model and a spline model with a knot at 1M SEK. The point estimates suggest the marginal effect of lottery wealth is smaller for larger prizes, but the difference is not statistically significant. Table A3.4 also shows the estimated effect is about $10 \%-20 \%$ larger when we exclude very large $(>5 \mathrm{M}$ SEK), large ( $>2 \mathrm{M})$, or moderate ( $>1 \mathrm{M}$ SEK) prizes.

Figure 3 reports the labor supply trajectories for different subsamples. The corresponding fiveyear event-study estimates are available in Table A3.5, where we also test for equal effects in different samples. Panel A in Figure 3 shows the effect is similar across lotteries, and we cannot reject the null hypothesis of equal effects (see Table A3.5). In particular, lump-sum prizes and (discounted) monthly installment prizes have similar effects on labor earnings, suggesting that confronting the data with a forward-looking dynamic labor supply model as we do in the following section is appropriate.

\section{[FIGURE 3 HERE]}

Standard life-cycle models predict stronger wealth effects in older workers because they have 
fewer years to spend the lottery prize. To test for heterogenous effects by age, we estimate equation (2) separately for three different age groups (21-34, 35-54, and 55-64). Panel B in Figure 3 shows the effect is surprisingly similar in the years immediately following the lottery event (and Table A3.5 confirms no statistically significant difference exists). We find a tendency of a smaller response for the oldest age group five to 10 years after winning the lottery; this tendency is due to a large fraction in this age group reaching retirement age, which mechanically attenuates the effect of the wealth shock.

A common finding in the literature is that labor supply elasticities are larger for women than men (Keane, 2011). Panel C in Figure 3 shows the tendency is the opposite in our data, although the difference between men and women is not significantly different from zero. Panel D in Figure 3 shows the response is similar for individuals with and without a college degree. Finally, Panel E in Figure 3 indicates the earnings response is higher for winners with high pre-lottery earnings. The event-study estimate reported in Table A3.5 is about twice as large for high earners compared to those with low or medium earnings, but the difference is not statistically significant. However, high-income earners face higher marginal tax rates, and as a consequence, the difference in the after-tax earnings response is smaller (see Panel F in Figure 3 and Table A3.5).

\section{Dynamic Labor Supply Model}

In this section, we estimate a simple dynamic life-cycle labor supply model using a simulated minimum-distance procedure. We use the simulated model for two purposes. The first is to recover a model-based estimate of the long-run, lifetime effect of a lump-sum lottery prize on aftertax labor earnings. The second purpose of the model is to recover estimates of key labor supply

elasticities, such as the uncompensated (Marshallian), compensated (Hicksian), and intertemporal (Frisch) labor supply elasticities. 


\section{A. Model Setup}

The model is a discrete-time, dynamic labor supply model with perfect foresight, no uncertainty, and no liquidity constraints. The agent lives for $T$ periods $(t=0,1, \ldots, T-1)$ and receives unearned income $a_{t}$ in period $t$. Each period, the agent chooses consumption $c_{t}$, annual work hours $h_{t}$, and next period's assets $\left(A_{t+1}\right)$. Annual earnings $\left(y_{t}\right)$ are the product of the after-tax wage $w_{t}$ and annual hours. Assets earn interest rate $r$ between periods. Individuals in the model will choose to save for retirement, which must occur at $t=R^{*}$ or earlier; at this time, individuals can no longer choose $h_{t}>0$. The per-period utility function is Stone-Geary, as in Imbens et al. (2001). ${ }^{12}$ Individuals make consumption, labor supply, and savings/borrowing decisions to maximize lifetime present discounted utility (using a discount rate $\delta$ ), according to

$$
\begin{aligned}
U & =\sum_{t=0}^{T-1} \frac{1}{(1+\delta)^{t}}\left(\beta \log \left(c_{t}-\gamma_{c}\right)+(1-\beta) \log \left(\gamma_{h}-h_{t}\right)\right), \\
A_{t+1} & =(1+r)\left(A_{t}-c_{t}+w_{t} h_{t}+a_{t}\right), \\
A_{T} & \geq 0 \\
h_{t} & =0 \forall t \geq R^{*} .
\end{aligned}
$$

A lump-sum lottery prize is represented as a one-time shock to $A_{0}$. The empirical results provide individual-level estimates of $d\left(y_{t}\right) / d A_{0}$ for each time period following the lottery win. Before describing the simulation strategy, we discuss the role of three important model assumptions.

No Barriers to Saving and Borrowing. We assume agents can save and borrow at interest rate $r$. An implication of the no-barrier assumption is that within the model, two prizes with identical present discounted values should have the same dynamic effects on labor earnings. This model prediction is consistent with our reduced-form analysis, which find similar results for TrissLumpsum and Triss-Monthly prizes; however, liquidity effects rather than "pure" wealth effects

\footnotetext{
${ }^{12}$ The per-period utility function is $\beta \log \left(c_{t}-\gamma_{c}\right)+(1-\beta) \log \left(\gamma_{h}-h_{t}\right)$. The parameter $\beta$ is the relative weight on consumption in utility, $\gamma_{c}$ is the subsistence term for consumption, and $\gamma_{h}$ is the maximum annual hours of work available.
} 
might account for some of the estimated labor earnings response, as discussed in Chetty (2008).

Stone-Geary Functional Form. Stone-Geary preferences simplify the simulation because the per-period problem can be solved in closed form. Additionally, in a static model, this functional form delivers an income effect that does not vary with the wage, which is consistent with our reduced-form finding that the after-tax earnings response is similar in different income groups.

Binding Retirement Age. The Swedish retirement system admits flexibility in the timing of retirement, but as we discuss further in section 6 in the OA, a binding retirement age at 65 is a reasonable simplifying assumption. We find clear evidence of "bunching" of retirement ages around age 65 , with some retirement before age 65 , but very little retirement after age 65 . The model also contains no incentive to retire early, because individuals prefer to smooth leisure and consumption over the life cycle. In line with this feature of the model, we find no statistically significant effect for pension income on the extensive margin for individuals who win prizes in their 50s and 60s (see Table 4), although we see a small positive effect on the intensive margin (as shown in Table 3).

The binding retirement age allows the simulated model to more closely fit the reduced-form empirical results. Models without a binding retirement age will generally predict much stronger variation in annual earnings responses by age (i.e., $T$ ), as discussed in Imbens et al. (2001). Intuitively, in models without retirement, individuals will smooth their annual reductions in labor earnings over the remaining years of working life, so annual earnings declines will be larger for older winners with fewer remaining years of life left. For example, in the model above with $\delta=r$ and $T=R^{*}$, the overall lifetime earnings reduction is independent of age. Moreover, in standard models without retirement, the time pattern of the dynamic effect of a lottery win will not vary with age. Both of these features of a standard model contrast with our main results. The immediate labor supply response is fairly similar for all age groups, and whereas younger workers exhibit roughly constant effects over time, the earnings effect declines over time for older workers. The binding retirement age can account for both of these features. First, with a binding retirement age, individuals 
will save some of their lottery winnings into retirement, which attenuates the relationship between the immediate earnings reduction and age. Second, the annual earnings response mechanically goes toward zero for older winners as these older workers reach the binding retirement age.

The model carries some important caveats. For example, the reduced-form results showed that winners partly adjust labor supply along the extensive margin, which the model does not capture because it contains no extensive margin decision. The estimated structural parameters may also be sensitive to alternative assumptions regarding the role of uncertainty in determing labor supply.

\section{B. Model Simulation}

We simulate the model to find the combination of parameters that produces simulated results that most closely match the main individual-level results. ${ }^{13}$ The years of life remaining depend on the age of the winner when the prize is awarded. When simulating the model, we match the empirical distribution of the age of winners in the data. Individuals retire at age 65 and die at age 80, so a 25-year-old winner would face $T=55$ and $R^{*}=40$. We choose $r=0.02$ to match the average real risk-free rate in Sweden during the time period spanned by the data. We assume the subsistence consumption term is $\gamma_{c}=20,000$ SEK, which is about $12 \%$ of the median annual disposable income. We set the wage equal to average after-tax earnings divided by average hours worked in our data. Unearned income $a_{t}$ is set to 0 for all $t<R^{*}$ and to $70 \%$ of average annual after-tax earnings for $t \geq R^{*}{ }^{14}$

We estimate the three remaining parameters via simulation: the discount rate $(\delta)$, the maximum annual hours limit $\left(\gamma_{h}\right)$, and the relative weight on consumption in utility $(\beta)$. For a given value of $r$, the time path of labor earnings following the lottery helps pin down $\delta$. If $\delta>r$, short-run reductions in earnings should be larger than long-run reductions. ${ }^{15}$ The lifetime earnings reduction

\footnotetext{
${ }^{13} \mathrm{OA}$ section 5 shows how the model can be recast as a dynamic programming problem.

${ }^{14}$ We make the simplyfing assumption that pension income does not respond to labor earnings prior to retirement. Details about the Swedish pension system is available in OA section 6.

${ }^{15}$ This discussion of identification is meant to convey intuition, but the actual identification of $\delta$ is more subtle. The binding retirement age will also cause the earnings reductions to decline over time mechanically as winners reach the binding retirement age.
} 
to winning the lottery is primarily determined by the value of $\beta$, because this parameter governs the strength of the income effect. Given the other two parameters, the value of $\gamma_{h}$ determines the optimal choice of hours worked. The parameter $\gamma_{h}$ is therefore primarily identified by the average actual hours worked in our data. ${ }^{16}$

We estimate the three parameters using a standard simulated minimum-distance procedure. For each set of parameters, we simulate the model and compute the effect of winning the lottery (i.e., $\left.d\left(y_{1}\right) / d A_{0}, \ldots, d\left(y_{10}\right) / d A_{0}\right)$, as well as the average annual hours $\bar{H}=\frac{1}{T} \sum_{t=1}^{t=10} h_{t}$. We calculate these statistics for each simulated individual and then average across individuals (weighting individuals so that the age distribution in the simulated sample matches the empirical distribution). The simulation procedure is repeated many times to find the combination of parameters that comes closest to matching the reduced-form effect of the lottery win. See OA section 5 for details about the minimum-distance criterion we use and how we estimate standard errors.

\section{Simulation Results and Implied Labor Supply Elasticities}

Table 5 summarizes the simulation results. The $\chi^{2}$ goodness-of-fit test statistic is not large $\left(\chi^{2}(8)=3.43, p=0.095\right)$, suggesting the model provides a reasonably good fit to the reducedform results. The estimate of $\beta$ is 0.845 (s.e. 0.010 ), suggesting that (holding marginal utility of wealth constant) roughly $15 \%$ of unearned income is spent reducing after-tax labor earnings, with the rest spent increasing consumption. The estimate of $\delta$ is 0.010 (s.e. 0.005), implying that longrun response of a wealth shock is slightly larger than the short-run response. While this may seem to contradict the time-pattern of responses in Figure 1, recall that the estimated effect is attenuated as workers reach retirement age. Because the model incorporates retirement, $\delta$ is mainly pinned

\footnotetext{
Therefore, the full structure of the model is needed to separate the mechanical effect of retirement from the effect of $\delta>r$. Another way to think about the identification of $\delta$ would be to focus on younger winners who would not face the binding retirement age during the 10 years following a lottery win. For these winners, the time path of earnings response can be used to directly identify $\delta$, given $r$.

${ }^{16}$ To gain intuition for how $\gamma_{h}$ is identified, consider a static, one-period problem with no unearned income and Stone-Geary preferences. In this case, the optimal-hours choice is given by $h=\beta \gamma_{h}+(1-\beta) \gamma_{c} / w$. With no subsistence consumption $\left(\gamma_{c}=0\right)$, then $h=\beta \gamma_{h}$. Therefore, observed hours worked will directly inform $\gamma_{h}$, given $\beta$. In the data, the average annual hours worked is 1,566 hours, which corresponds to workers in our sample working $82.8 \%$ of full-time on average (which corresponds to 1,880 annual hours). This estimate comes from the analysis sample used to estimate the effect of the lottery on wages, restricting to individuals with annual earnings greater than 25,000 SEK.
} 
down by the response pattern of workers who are not close to retirement. Panel B of Figure 3 shows the labor supply responses of young and middle-aged winners does not vary systematically with time since the lottery. The estimate of $\gamma_{h}$ (which can be interpreted as the maximum annual hours of work available) is $1,870.0$ (s.e. 39.7 ), close to the 1,880 hours that characterizes full-time work in Sweden.

\section{[TABLE 5 HERE]}

Figure 4 compares the simulated model to the reduced-form effects of lottery wealth on aftertax income. Consistent with the relatively low $\chi^{2}$ test statistic, the model-based estimates track the empirical estimates fairly closely. Panel B of Table 5 compare simulated results to empirical results that were not directly "targeted" in estimation, focusing on differences in the after-tax response by age, size of prize amount, and pre-win earnings of the winner. Our simulation results are broadly in line with the empirical results which show fairly limited variation across each of these sources of individual heterogeneity. ${ }^{17}$

\section{[FIGURE 4 HERE]}

Estimating the Lifetime Marginal Propensity to Earn. Using the estimates of the model, we can compute the lifetime marginal propensity to earn (after-tax) income out of unearned income, where the calculation extrapolates beyond the first 10 years following the lottery win to the entire remaining years of life. The model estimates imply lifetime MPEs that vary with age at the time of win, from -0.20 for 20 -year-old winners to -0.05 for winners aged 60 (see column 1 in Panel A of Table 6). The second and third columns show the cumulative wealth effect over the first 10 years (following prize) and the share of lifetime effect that is accounted for by the 10-year effect. For older lottery winners near (binding) retirement, the lifetime effect and the 10-year effect are

\footnotetext{
${ }^{17}$ Despite the many simplifying assumptions, we note that the model can also provide a reasonable fit for asset accumulation over the life cycle in a Swedish representative sample. Figure A2.3 shows the simulated asset path for a 25-year-old non-winner together with the median and mean net wealth by age in a Swedish representative sample in year 2000. The simulated model assumes lifespan ends at 80 and no bequest motive exists; either a bequest motive or uncertain lifespan would allow the model to better fit the wealth data after age 65 .
} 
identical, because these winners all retire within 10 years. For younger winners, the lifetime wealth effect and 10-year effect diverge substantially. For winners between ages 20 and 45, most of the lifetime earnings reduction occurs after the first 10 years, implying that the cumulative 10-year effects significantly understate lifetime wealth effects. Although estimates previously reported in the literature vary widely, the average lifetime MPE in our data (-0.11) is fairly close to the median $(-0.15)$ among the 30 different estimates reported by Pencavel (1986). ${ }^{18}$ Incidentally, our average MPE is identical to the MPE reported by Imbens et al. (2001) when they exclude non-winners and winners of extremely high prizes from their data. ${ }^{19}$

\section{[TABLE 6 HERE]}

Recovering Key Labor Supply Elasticities. In Panel B of Table 6, the model-based parameter estimates are used to recover estimates of key labor supply elasticities that feature prominently in previous research: the uncompensated (Marshallian) elasticity, the compensated (Hicksian) elasticity, and the intertemporal (Frisch) elasticity. Using the model parameters from Table 5, simulating these elasticities is straightforward. The simulated elasticities are shown in Panel B of Table 6 for an individual who wins at age 50. The uncompensated elasticity is very small in magnitude, which is a direct consequence of the Stone-Geary functional-form assumption (because the income and substitution effects are similar by assumption). The Hicksian elasticity is estimated to be around 0.1 , which is smaller than the average Hicksian elasticity estimate of 0.31 reported in the metaanalysis in Keane (2011). The Frisch elasticity is estimated to be close to 0.2 , which is smaller than the range of estimates $(0.27-0.53)$ used by the Congressional Budget Office (Reichling and

\footnotetext{
${ }^{18}$ Two recent studies that consider settings similar to ours find substantially larger MPEs than we do. Kimball and Shapiro (2008) estimate an MPE of -0.37 using survey responses about hypothetical lottery winnings, whereas Bengtsson (2012) estimate an MPE of about -0.30 among recipients of unconditional cash grants in South Africa.

${ }^{19}$ The similarity in terms of average MPEs masks non-trivial differences in estimation and modelling. Plugging our event-study estimate for the after-tax response (column 8 of Table 3) into the model in Imbens et al. (2001) gives an MPE of -0.05 . The reason for the lower MPE is that Imbens et al. (2001) assume $\delta=r=0.10$ whereas we assume $r=0.02$ and estimate $\delta$ to be 0.01 . A high interest rate implies lump-sum prizes are "large" relative to yearly installments (the setting studied by Imbens et al., 2001), attenuating the MPE based on our estimates. The same exercise with $\delta=r=0.02$ gives an MPE based on our estimates of -0.13 compared to -0.14 based on the estimates in Imbens et al. (2001). The reason for the higher MPE compared to our calibration is the high implicit retirement age in Imbens et al. (2001). Since they assume winners continue working for 30 years, the implicit average retirement age would be 78 in our sample and 80 in Imbens et al. (2001).
} 
Whalen, 2012). Although these specific elasticities are recovered from the reduced-form incomeeffect estimates and the functional-form assumptions of the dynamic model, we emphasize that the specific Stone-Geary functional form does not entirely drive the estimated elasticities. In a wide range of time-separable utility models, the Frisch elasticity and the Hicksian elasticity are related by the intertemporal elasticity of substitution (IES), the estimated income effect, and the ratio of wealth to income (Ziliak and Kniesner, 1999; Browning, 2005). Therefore, modest estimates of the income effect necessarily constrain the Frisch elasticity to be similar in magnitude to the Hicksian elasticity, as long as the IES is not very large. ${ }^{20}$

\section{Household-level Analyses}

Two questions guide our household-level analyses. First, because of spillovers between spouses or sharing of lottery prizes, restricting attention to winners may lead us to underestimate the total effect of lottery wealth on labor supply. Second, the lottery wealth shocks allow us to test the unitary model of the household, according to which the identity of the lottery winner should not affect how households adjust their labor supply. To see why the unitary model has this prediction, consider the following simplified, static version of the model estimated by Blundell et al. (2014). Households consist of two adults that jointly solve the following static labor supply problem:

$$
\begin{aligned}
& \max _{C, H^{1}, H^{2}} U\left(C, H^{1}, H^{2}\right) \\
& \text { s.t. } C=A^{1}+A^{2}+H^{1} w^{1}+H^{2} w^{2},
\end{aligned}
$$

\footnotetext{
${ }^{20}$ If lifetime utility is addititively separable, and there is perfect foresight, no uncertainty, and perfect capital markets, the relation between the Frisch $\left(e_{F}\right)$ and the Hicksian $\left(e_{H}\right)$ elasticity is

$$
e_{F}=e_{H}+\rho\left(\frac{d w h}{d A}\right)^{2} \frac{A}{w h}
$$

where $\rho$ is the IES, $d(w h) / d A$ is the income effect, and $A /(w h)$ is the ratio of wealth to income (see Ziliak and Kniesner, 1999 and Browning, 2005). In the calibration in Panel B of Table $6, e_{H}$ is roughly $0.11, \rho$ is roughly 1 given Stone-Geary utility, the income effect is roughly 0.11 , and the ratio of $A /(w h)$ is approximately 8 . This implies an estimate of $e_{F}$ of 0.21 , which is close the value calculated directly from model simulation. Assuming a small Marshallian elasticity, $e_{H}$ and the income effect will be similar in magnitude from the Slutsky equation. A large Frisch elasticity consequently requires a large value of IES. A doubling of IES to 2.0 would still give a value of Frisch below 0.4 .
} 
where $C$ is total household consumption, $H^{i}$ is the labor supply of individual $i, w^{i}$ is the wage of individual $i$, and $A^{i}$ is unearned income (assets) owned by individual $i$. A straightforward implication of this model is "exogenous income pooling," which can be formally expressed as $d H^{i} / d A^{1}=d H^{i} / d A^{2}$ for $i=1,2$. In the context of lotteries, income pooling implies the household labor supply response to a lottery win is independent of which spouse owned the lottery ticket.

Before addressing these two questions, we begin with a short discussion of how lottery wealth is allocated between spouses. In both the PLS and the Kombi lottery, the lottery-ticket owner is clearly defined, because the winning account (PLS) or lottery ticket subscription (Kombi) pertains to a specific individual. The division of ownership of Triss lottery tickets within a married couple is less clear, because couples may sometimes buy the lottery ticket that qualifies them to be on the TV show together. ${ }^{21}$ To analyze how lottery wealth is allocated within couples, we regress net wealth at the end of the year of the win on the lottery prize. Net wealth is based on annual data from the Wealth Registry, which includes detailed information on individuals' year-end net wealth holdings between 1999 and 2007. ${ }^{22}$ Given the limited time span of the Wealth Registry, we observe wealth for very few winners in PLS; therefore, we restrict attention to the Triss-Lumpsum and Kombi lotteries. ${ }^{23}$ Table A3.6 shows winners keep significantly more for themselves in both lotteries; non-winning spouses in Triss-Lumpsum receive $32 \%$ of the increase in registered net wealth in the year of winning, whereas spouses to Kombi winners receive 18\%. As Figure A2.4 shows, winners keep most of the prize money for themselves in each of the 10 years following the lottery win. As a rough benchmark for PLS, Panel C in Table A3.6 shows the effect of lottery prizes on capital income for the PLS sample. Non-winning spouses in PLS receive $12 \%$ of the increase

\footnotetext{
${ }^{21}$ As noted in Section I.B., the Triss data contain information about shared ownership of lottery tickets, but the data rarely indicate shared ownership between married spouses, probably because "contracts" regarding ownership are less explicit between spouses, and because wealth is split equally in the event of a divorce. Consequently, in some cases married couples are likely to have bought a winning ticket together, but only one of the spouses appears on the show.

${ }^{22}$ The wealth measure does not include cash, cars, or other durables, merchandise, assets transferred to other family members, or money that has been concealed from the tax authority. The estimated effect of lottery wealth on year-end wealth at $t=0$ (on average 6 months after the lottery) therefore only gives an upper bound on the fraction of the wealth shock that is consumed in the year of the lottery.

${ }^{23}$ We exclude Triss-Monthly winners because it is difficult to infer how the prize money is allocated within couples when it is paid out over long time.
} 
in household capital income, suggesting PLS winners retain most of the lottery wealth. Winners consequently seem to retain control of a larger share of the lottery prize wealth than spouses in all lotteries, but less so in Triss-Lumpsum.

To analyze the household labor supply response, Table 7 shows the five-year event-study effect on gross labor earnings for married and unmarried winners and the whole sample. For married winners, we report winner, spousal, and household labor supply, as well as the difference between winner and spousal labor supply. In the full sample, we include the labor supply of non-winning spouses when calculating household labor supply. The individual-level labor supply response in the full sample is identical to the specification reported in column (1) of Table 2. Figure 5 shows the corresponding dynamic effects.

\section{[TABLE 7 HERE]}

Table 7 shows the labor supply of married winners drops by 0.98 SEK for each 100 SEK won, compared to 0.46 for their spouses. The labor supply of the household is hence reduced by 1.44 SEK per 100 SEK. While married winners reduce their labor supply by less than unmarried winners (0.98 SEK compared to $1.26 \mathrm{SEK}$ ), the total response of married couples is larger than for singles. In the full sample, including the response of non-winning spouses therefore increases the labor supply response from -1.07 to -1.32 . Focusing only on winners thus leads to an underestimation of the labor supply response by about $24 \%$.

\section{[FIGURE 5 HERE]}

Table 7 shows married winners reduce their labor supply by 0.52 SEK more than their spouses for every 100 SEK won $(p=0.059)$, which contradicts income pooling. To more carefully assess the income-pooling hypothesis, we restrict attention to PLS and Kombi because Triss lottery tickets may be jointly owned. We also restrict the sample to couples in which both spouses (not just the winner) were between age 21 and 64 at the time of winning. As Panel A in Table A3.7 shows, the 
difference between the labor supply response of the winner (-1.14) and the non-winning spouse $(-0.36)$ in this subsample is 0.79 SEK per 100 SEK won $(p=0.057)$. The difference is larger than the differential effect reported in Table 7, which is consistent with the conjecture that Triss lottery tickets are more likely to be jointly owned. Panel B in Table A3.7 shows the estimated difference is similar when we further restrict the sample to couples in which both spouses were below age 59 at the time of winning, so that no spouse reaches retirement age during the five-year period $(-0.88$, $p=0.049$ ). As Panel C shows, winners also react more strongly than their non-winning spouses in terms of after-tax income $(-0.35, p=0.048)$. The different specifications in Table A3.7 shows between $70 \%$ and $90 \%$ of the total household labor supply reduction is due to the winner, which is in line with how lottery wealth is allocated between spouses. In additional analyses reported in Table A3.8, we find no clear evidence that the effect of lottery wealth on winner and spousal earnings depends on the winner's sex or whether the primary or secondary earner wins the lottery. ${ }^{24}$

Our identification strategy only allows us to leverage variation in wealth that is random across, but not within, households. Therefore, non-winning spouses might differ systematically from winners in a way that is correlated with the labor supply response to a positive wealth shock. In an attempt to reduce the concern of non-random assignment of wealth between spouses, we restrict the sample to couples in which the non-winning spouse participated in the winning draw or prewin draws in the same lottery. As a second robustness test, we go further and restrict the sample to couples in which both spouses participated in the winning draw. Imposing these restrictions implies that we also move closer to random assignment of lottery wealth within married couples. ${ }^{25}$ The last two panels of Table A3.7 show that imposing these restrictions strengthens the differential

\footnotetext{
${ }^{24}$ Because of the smaller sample size, standard errors are relatively large in these subsamples. When including the Triss sample, we obtain suggestive evidence that the differential response is stronger when the husband or the primary earner wins the lottery.

${ }^{25}$ Table A3.7 (Panel A) shows winners in PLS held on average 170 tickets in the winning draw, compared to 48 for their spouses. The corresponding numbers for Kombi are 1.48 and 0.09. Restricting the sample to spouses that participated in the lottery (Panel D), PLS winners had 166 tickets compared to 75 for spouses; Kombi winners had 1.51 tickets and their spouses had 0.90. Restricting the sample to spouses that participated in the winning draw (Panel E) causes little change in the number of tickets held by the winners, but increases the average among spouses to 115 (PLS) and 1.26, respectively. Table A3.9 shows the differences between winning and non-winning spouses in terms of demographic characteristics are always small in PLS, whereas winners in Kombi earn more than their spouses and are more likely to be male. Restricting the sample to couples in which both spouses participated in the lottery reduces (but does not eliminate) these differences in Kombi.
} 
response between winning and non-winning spouses.

Another concern with our household-level results is that lottery wealth might affect household composition. As discussed in OA section 9, our point estimates suggest lottery wealth increase divorce risk, but the effect is small and not statistically significant. OA section 9 also shows that our results do not change appreciably when the sample is restricted to couples that remain married.

\section{A. Models of Household Labor Supply}

The household-level results suggests the identity of the winner determines who in a married couple reduces labor supply the most, which is inconsistent with the unitary model. Reconciling our results with household bargaining models that rely on divorce as the only threat point is also hard. According to Swedish marriage law, the default rule in the event of divorce is that all assets are

divided equally between spouses, unless the couple has a prenuptial agreement. Prenuptial agreements are uncommon (see OA section 7 for further details) and lottery winnings will therefore, in most cases, affect the outside option of the winner and spouse symmetrically.

Instead, our results appear consistent with the "separate spheres" bargaining model of Lundberg and Pollak (1993) that relies on threat points internal to the marriage. As long as a couple remains married, the winner owns and controls the prize money unless he or she decides to transfer part of the prize to the non-winning spouse, or deposit the money in a joint account. Lottery wealth can therefore improve the bargaining power of the winner by making the winner better off in the within-marriage non-cooperative equilibrium that defines the threat point in Lundberg and Pollak (1993). Following Chiappori and Donni (2009), an alternative model consistent with our results is one in which the weights on each household member's individual utility function is endogenous to the distribution of wealth and unearned income within the household. In this model, the household collectively maximizes a household welfare function with weights that are affected by the lottery outcome, and the identity of the lottery winner matters because individual lottery winnings change the relative welfare weights through a weighting function. 


\section{Conclusion}

We have shown that there is an immediate and permanent change in labor earnings in response to an exogenous wealth shock. The magnitude of the response is modest; pre-tax labor earnings decrease by about $1 \%$ of the wealth shock in each of the first 10 years following the win. The response is about $40 \%$ smaller when we instead consider after-tax income, and about $40 \%$ larger when we measure labor supply in terms of production value (labor earnings including employerpaid social security contributions). The earnings response is due to a reduction in both wage earnings and self-employment income.

A large part of the adjustment takes place along the intensive margin, suggesting individuals in our context do not face large, costly barriers to adjusting their labor supply. Another surprising finding is the limited heterogeneity across many interesting demographic subgroups. Imbens et al. (2001) similarily find no significant differences in the responses of men and women, and note this finding is at odds with a large literature that finds women are systematically more responsive to price and wealth changes. Perhaps even more surprising is the lack of heterogeneity in wealth effects by age. A standard life-cycle labor supply model suggests larger wealth effects as retirement approaches. We reconcile this finding with the past literature by calibrating a dynamic labor supply model with a binding retirement age and show this calibrated model can match our results. Because the estimated wealth effect is modest, our calibrated model implies labor supply elasticities which are in the lower range of previously reported estimates.

In our household-level analyses, we find both winners and spouses reduce their labor supply, but the reduction is stronger for winners. This finding provides unusually strong evidence against the testable prediction of unitary models of household labor supply that exogenous unearned income is pooled within the household. 


\section{REFERENCES}

Andersen, Steffen and Nielsen, Kasper Meisner. (2012). 'Ability or Finances as Constraints on Entrepreneurship? Evidence from Survival Rates in a Natural Experiment', Review of Financial Studies 25(12), 3684-3710.

Arvey, Richard D. and Liao, Itzhak Harpaz \& Hui. (2004). 'Work Centrality and the PostAward Behavior of Lottery Winners', Journal of Psychology 138(5), 404-420.

Bengtsson, Niklas. (2012). 'The Marginal Propensity to Earn and Consume out of Unearned Income: Evidence Using an Unusually Large Cash Grant Reform', The Scandinavian Journal of Economics 114(4), 1393-1413.

Blundell, Richard and MaCurdy, Thomas. (2000), Labor Supply: A Review of Alternative Approaches, in Orley Ashenfelter and David Card., eds, 'Handbook of Labor Economics', Vol. 3, North-Holland, chapter 27, pp. 1559-1695.

Blundell, Richard, Pistaferri, Luigi and Saporta-Eksten, Itay. (2014), Consumption Inequality and Family Income Supply, European Central Bank Working Paper No 16561656.

Bodkin, Ronald. (1959). 'Windfall Income and Consumption', American Economic Review 49(4), 604-614.

Browning, Martin. (2005). 'A working paper from April 1985: Which demand elasticities do we know and which do we need to know for policy analysis?', Research in Economics 59(4), 293320.

Cesarini, David, Lindqvist, Erik, Östling, Robert and Wallace, Björn. (2015), Wealth, Health, and Child Development: Evidence from Administrative Data on Swedish Lottery Players, Forthcoming in Quarterly Journal of Economics. 
Chetty, Raj. (2008), Moral Hazard vs. Liquidity and Optimal Unemployment Insurance, NBER Working Paper No 13967.

Chetty, Raj, Friedman, John N., Olsen, Tore and Pistaferri, Luigi. (2011). 'Adjustment Costs, Firm Responses, and Micro vs. Macro Labor Supply Elasticities: Evidence from Danish Tax Records', The Quarterly Journal of Economics 126(2), 749-804.

Chiappori, Pierre-André and Donni, Oliver. (2009), Non-unitary Models of Household Behavior: A Survey of the Literature, IZA Discussion Paper No 4603.

Furåker, Bengt and Hedenus, Anna. (2009). 'Gambling Windfall Decisions: Lottery Winners and Employment Behavior', UNLV Gaming Research \& Review Journal 13(2), 1-15.

Hedenus, Anna. (2009). 'Time for Work or Time for Family? Work-life balance after winning the lottery', World Leisure Journal 51(1), 27-38.

Hirano, Keisuke and Imbens, Guido. (2004), The Propensity Score with Continuous Treatments, in Andrew Gelman and Xiao-Li Meng., eds, 'Applied Bayesian Modeling and Causal Inference from Incomplete-Data Perspectives', New York: Wiley, chapter 7, pp. 73-84.

Holtz-Eakin, Douglas, Joulfaian, David and Rosen, Harvey. (1993). 'The Carnegie Conjecture: Some Empirical Evidence', Quarterly Journal of Economics 108(2), 413-435.

Holtz-Eakin, Douglas, Joulfaian, David and Rosen, Harvey S. (1994). 'Sticking it Out: Entrepreneurial Survival and Liquidity Constraints', Journal of Political Economy 102(1), 53-75.

Imbens, Guido W., Rubin, Donald B. and Sacerdote, Bruce I. (2001). 'Estimating the Effect of Unearned Income on Labor Earnings, Savings, and Consumption: Evidence from a Survey of Lottery Players', American Economic Review 91(4), 778-794.

Joulfaian, David and Wilhelm, Mark O. (1994). 'Inheritance and Labor Supply', Journal of Human Resources 29(4), 1205-1234. 
Kaplan, H Roy. (1985). 'Lottery Winners and Work Commitment: A Behavioral Test of the American Work Ethic', Journal of the Institute for Socioeconomic Research 10(2), 82-94.

Keane, Michael. (2011). 'Labor Supply and Taxes: A Survey', Journal of Economic Literature 49(4), 961-1075.

Kearney, Melissa S., Tufano, Peter, Guryan, Jonathan and Hurst, Erik. (2011), Making Savers Winners: An Overview of Prize-Linked Savings Products, in Olivia Mitchell and Ammamaria Lusardi., eds, 'Financial Literacy: Implications for Retirement Security and the Financial Marketplace', Oxford University Press.

Kimball, Miles S and Shapiro, Matthew D. (2008), Labor Supply: Are the Income and Substituion Effects Both Large or Both Small?, NBER Working Paper No 14208.

Krueger, Alan B. and Pischke, Jörn-Steffen. (1992). 'The Effect of Social Security on Labor Supply: A Cohort Analysis of the Notch Generation', Journal of Labor Economics 10(4), 412 437.

Lagerwall, Björn. (2008), Real interest rates in Sweden, Sveriges Riksbank Economic Commentaries No 5.

Larsson, Bengt. (2011). 'Becoming a Winner But Staying the Same: Identities and Consumption of Lottery Winners', American Journal of Economics and Sociology 70(1), 187-209.

Lindh, Thomas and Ohlsson, Henry. (1996). 'Self-Employment and Windfall Gains: Evidence from the Swedish Lottery', The Economic Journal 106(439), 1515-1526.

Lundberg, Shelly and Pollak, Robert A. (1993). 'Separate Spheres Bargaining and the Marriage Market', Journal of Political Economy 101(6), 988-1010.

Lundberg, Shelly and Pollak, Robert A. (1996). 'Bargaining and Distribution in Marriage', The Journal of Economic Perspectives 10(4), 139-158. 
Mirrlees, James. (1971). 'An Exploration in the Theory of Optimal Income Taxation', The Review of Economic Studies 38(2), 175-208.

Pencavel, John. (1986), Labor Supply of Men: A Survey, in Orley Ashenfelter and Richard Layard., eds, 'Handbook of Labor Economics', Vol. 1, North-Holland, pp. 3-102.

Picchio, Matteo, Suetens, Sigrid and van Ours, Jan C. (2015), Labor Supply Effects of Winning a Lottery.

Prescott, Edward C. (1986). 'Theory Ahead of Business-Cycle Measurement', CarnegieRochester Conference Series on Public Policy 25, 11-44.

Rebelo, Sergio. (2005). 'Real Business Cycle Models: Past, Present and Future', The Scandinavian Journal of Economics 107(2), 217-238.

Reichling, Felix and Whalen, Charles. (2012), Review of Estimates of the Frish Elasticity of Labor Supply. Congressional Budget Office Working Paper Series 2012-13.

Saez, Emmanuel. (2001). 'Using Elasticities to Derive Optimal Income Tax Rates', The Review of Economic Studies 68(234), 205-229.

Saez, Emmanuel, Slemrod, Joel and Giertz, Seth H. (2012). 'The Elasticity of Taxable Income with Respect to Marginal Tax Rates: A Critical Review', Journal of Economic Literature 50, 350.

Taylor, Mark P. (2001). 'Self-Employment and Windfall Gains in Britain: Evidence from Panel Data', Economica 68(272), 539-565.

Ziliak, James P and Kniesner, Thomas J. (1999). 'Estimating Life Cycle Labor Supply Tax Effects', Journal of Political Economy 107(2), 326-359. 
Figure 1: Effect of Wealth on Individual Gross Labor Earnings

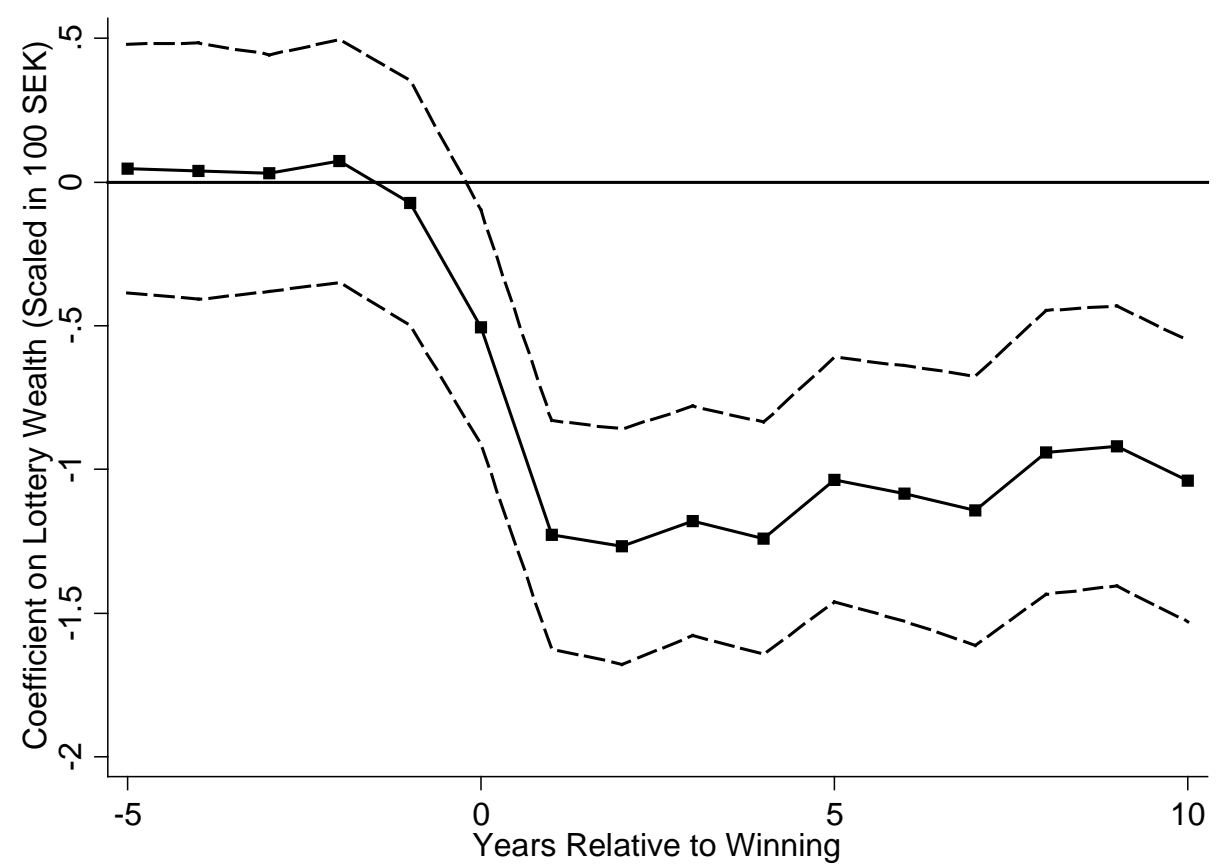

Notes: This figure reports estimates obtained from equation (2) estimated in the pooled lottery sample with gross labor earnings as the dependent variable. A coefficient of 1.00 corresponds to an increase in annual labor earnings of 1 SEK for each 100 SEK won. Each year corresponds to a separate regression and the dashed lines show 95\% confidence intervals. 
Figure 2: Margins of Adjustment

Panel A: Effect on Extensive Margin

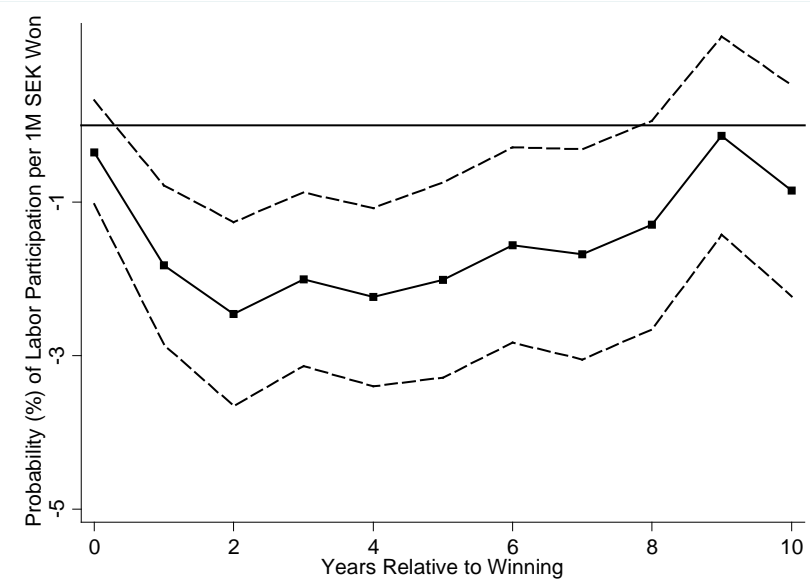

Panel C: Effect on Wages

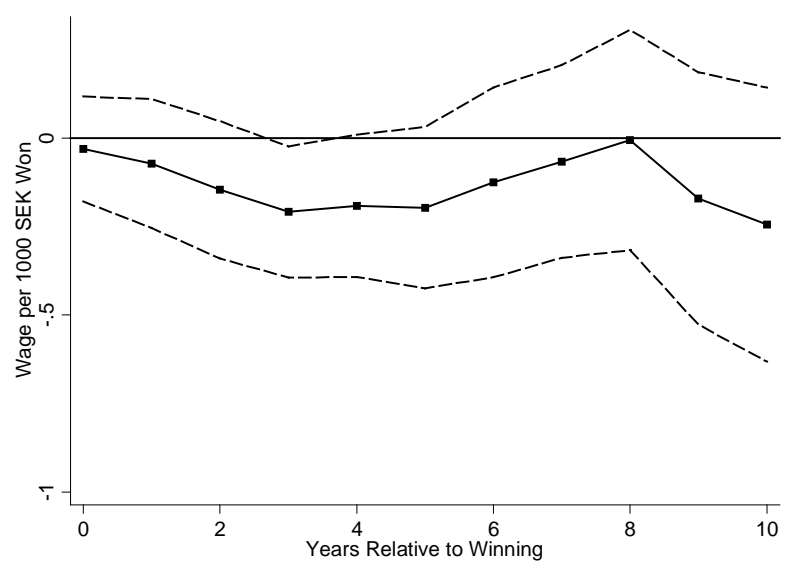

Panel E: Wages and Hours Decomposition

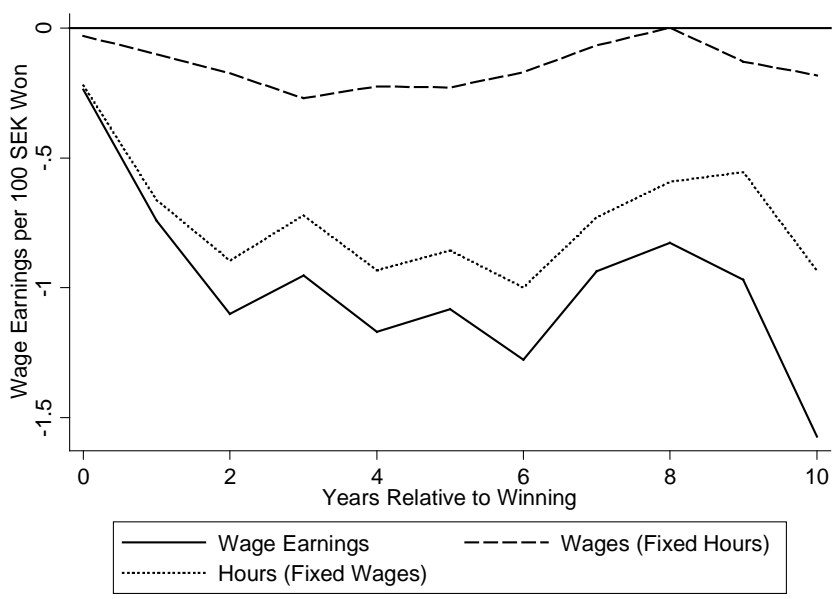

Panel B: Intensive vs. Extensive Margin

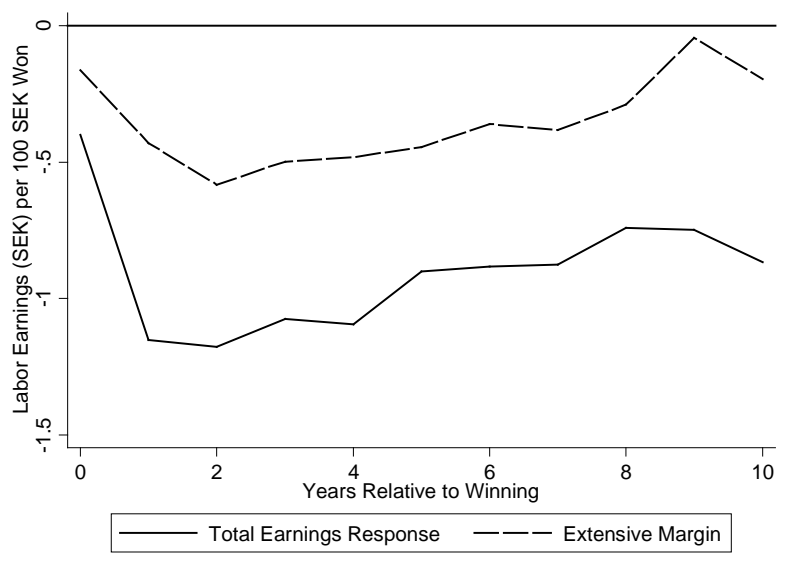

Panel D: Effect on Hours (Share of Full-Time)

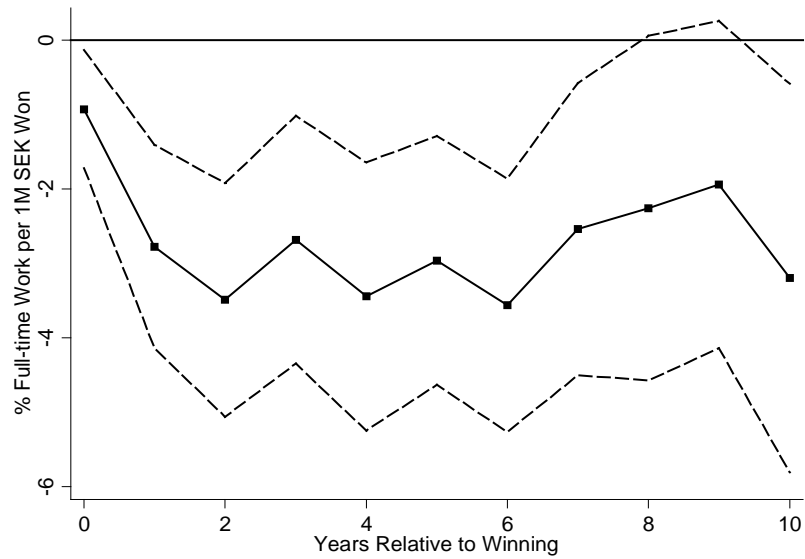

Panel F: Decomposition of Hours Worked

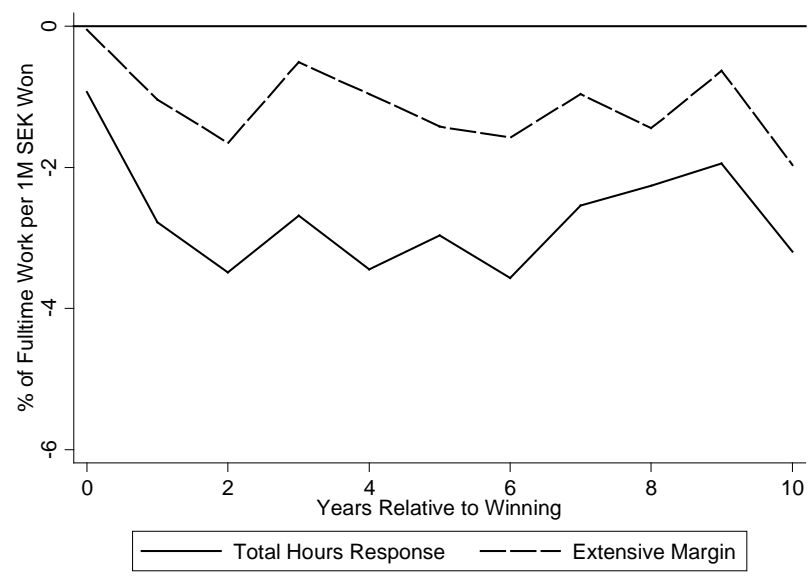

Notes: This figure reports estimates obtained from equation (2) estimated for the different outcomes discussed in section III.A. Each year corresponds to a separate regression. The dashed lines in Panel A, C, and D display 95\% confidence intervals. Panels A and B are estimated in the full sample, whereas Panels $\mathrm{C}$ to $\mathrm{F}$ are estimated in the subsample with observable wages. 
Figure 3: Heterogeneous Effects of Wealth on Earnings

Panel A: Heterogeneity by Lottery

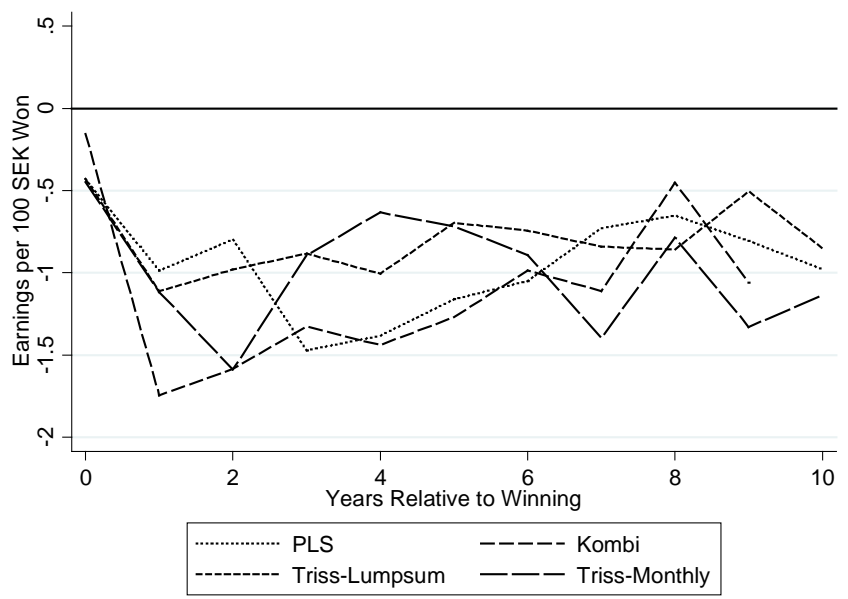

Panel C: Heterogeneity by Gender

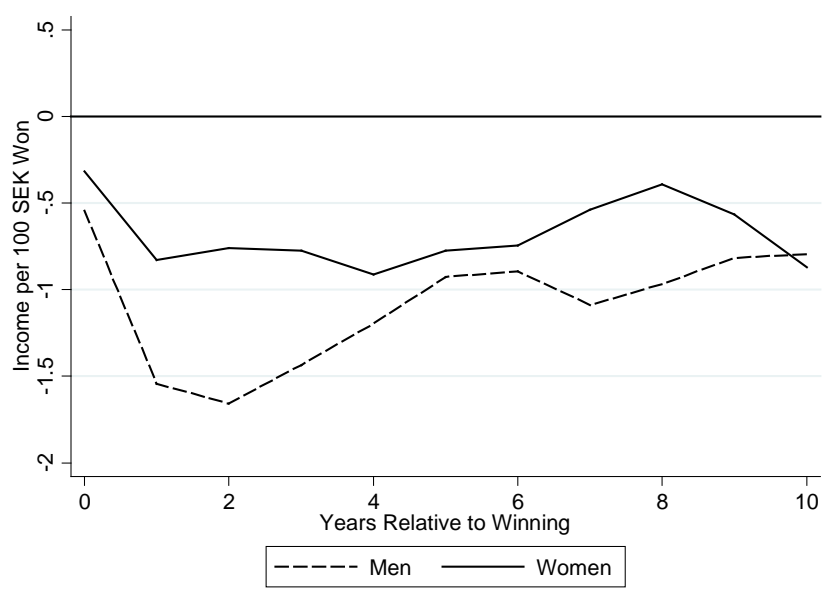

Panel E: Heterogeneity by Income Tercile (Pre-tax)

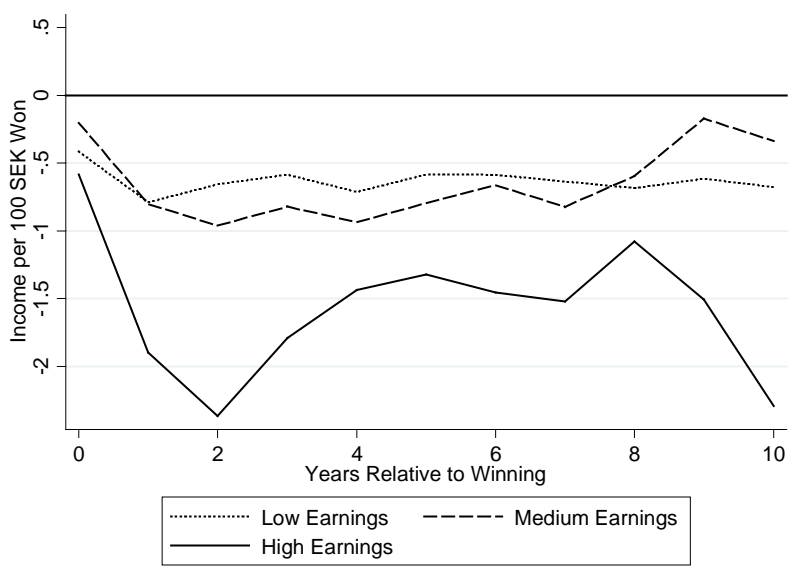

Panel B: Heterogeneity by Age

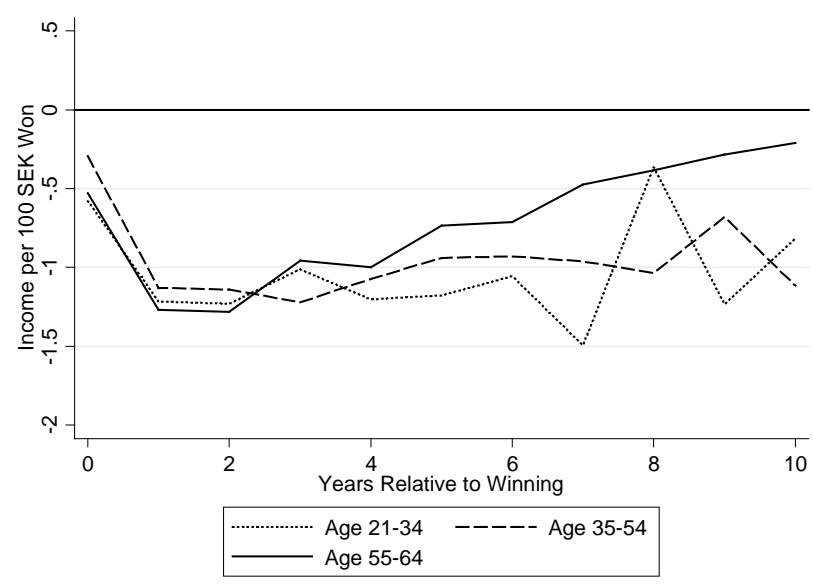

Panel D: Heterogeneity by Education

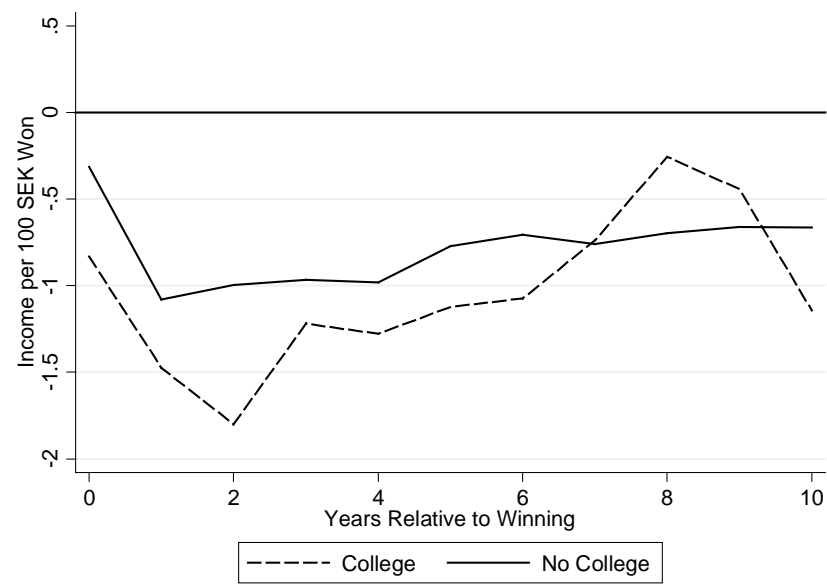

Panel F: Heterogeneity by Income Tercile (Post-tax)

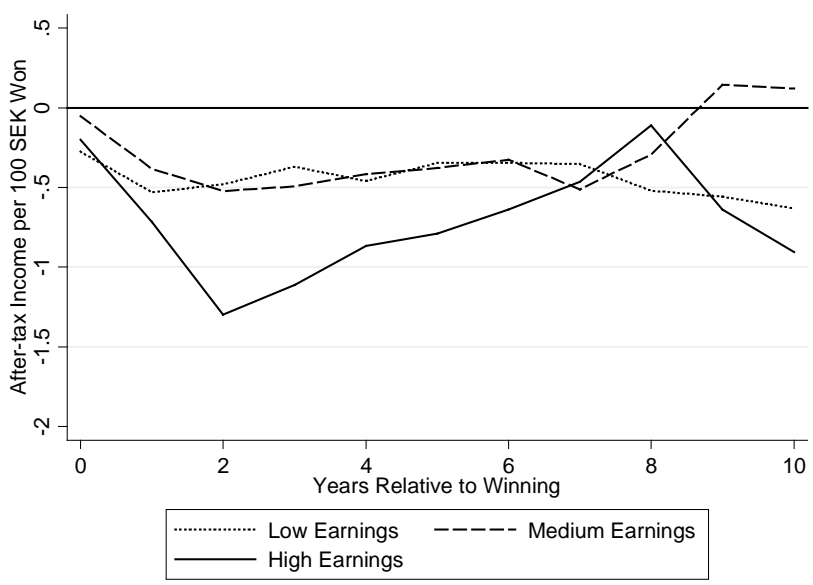

Notes: This figure reports estimates obtained from equation (2) estimated in different subpopulations. The dependent variable is gross labor earnings in Panel A to E and after-tax earnings in Panel F. A coefficient of 1.00 corresponds to an increase in annual earnings of 1 SEK for each 100 SEK won. Each year corresponds to a separate regression. The estimate for year 10 in Panel A is excluded for Kombi winners because very few observations are available. 
Figure 4: Comparing Model-Based Estimates to Empirical Results

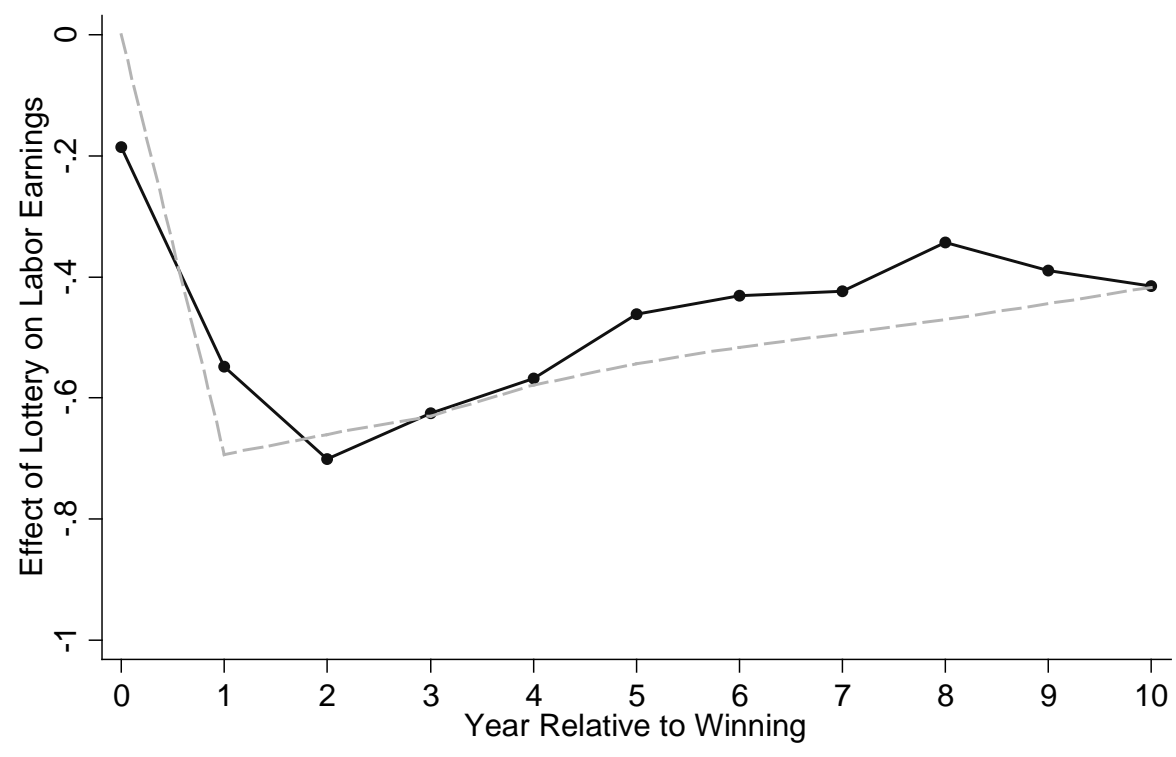

$\longrightarrow$ Pooled Sample Estimates $\quad-----$ Model-based Simulation

Notes: This figure compares the estimates obtained from equation (2) estimated in the pooled lottery sample with after-tax earnings as the dependent variable to the model-based estimates using the best-fit parameters reported in Table 5 . Year 0 correspond to the year the lottery prize is awarded, and in the simulation, the prize is assumed to be awarded at end of the year, so dy/dL for that year is 0 by assumption.

\section{Figure 5: Effect of Wealth on Gross Labor Earnings of Winners and Spouses}

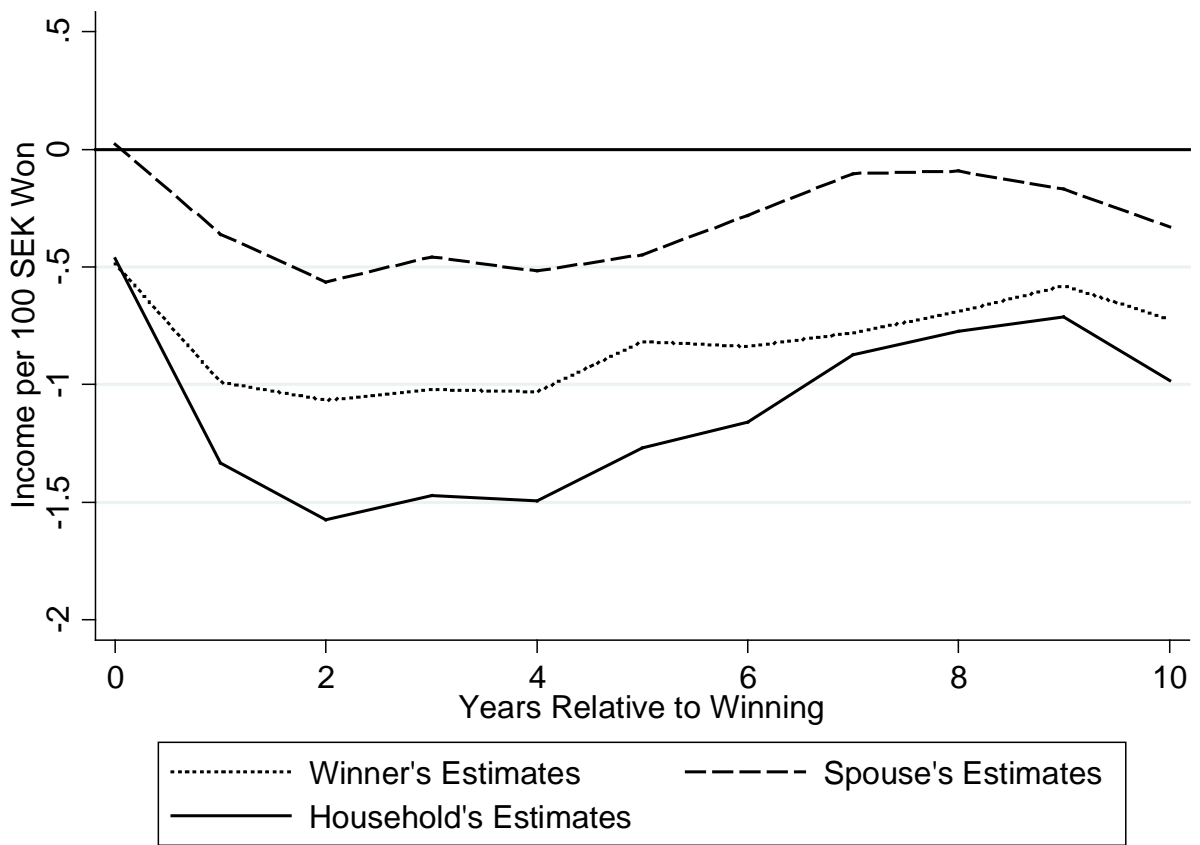

Notes: This figure reports estimates obtained from equation (2) estimated separately for winners, their spouses, and the household. The dependent variable is gross labor earnings. Each year corresponds to a separate regression. 
Table 1. Distribution of Prizes

\begin{tabular}{|c|c|c|c|c|c|c|c|c|c|c|}
\hline & \multirow{2}{*}{\multicolumn{2}{|c|}{ Pooled Sample }} & \multicolumn{8}{|c|}{ Individual Lottery Samples } \\
\hline & & & \multicolumn{2}{|c|}{ PLS } & \multicolumn{2}{|c|}{ Kombi } & \multicolumn{2}{|c|}{ Triss-Lumpsum } & \multicolumn{2}{|c|}{ Triss-Monthly } \\
\hline & Count & Share & Count & Share & Count & Share & Count & Share & Count & Share \\
\hline 0 to $1 \mathrm{~K}$ SEK & 25,172 & $10.0 \%$ & 0 & $0.0 \%$ & 25,172 & $99.0 \%$ & 0 & $0.0 \%$ & 0 & $0.0 \%$ \\
\hline $1 \mathrm{~K}$ to $10 \mathrm{~K}$ SEK & 204,626 & $81.3 \%$ & 204,626 & $92.0 \%$ & 0 & $0.0 \%$ & 0 & $0.0 \%$ & 0 & $0.0 \%$ \\
\hline $10 \mathrm{~K}$ to $100 \mathrm{~K}$ SEK & 16,429 & $6.5 \%$ & 15,520 & $7.0 \%$ & 0 & $0.0 \%$ & 909 & $27.8 \%$ & 0 & $0.0 \%$ \\
\hline $100 \mathrm{~K}$ to $500 \mathrm{~K}$ SEK & 3,685 & $1.5 \%$ & 1,654 & $0.7 \%$ & 0 & $0.0 \%$ & 2,031 & $62.1 \%$ & 0 & $0.0 \%$ \\
\hline $500 \mathrm{~K}$ to $1 \mathrm{M}$ SEK & 355 & $0.1 \%$ & 195 & $0.1 \%$ & 0 & $0.0 \%$ & 160 & $4.9 \%$ & 0 & $0.0 \%$ \\
\hline$\geq 1 \mathrm{M} \mathrm{SEK}$ & 1,481 & $0.6 \%$ & 481 & $0.2 \%$ & 263 & $1.0 \%$ & 168 & $5.1 \%$ & 569 & $100.0 \%$ \\
\hline TOTAL & 251,748 & & 222,476 & & 25,435 & & 3,268 & & 569 & \\
\hline
\end{tabular}

Notes: This table reports the distribution of lottery prizes for the pooled sample and the four lottery subsamples.

Table 2. Effect of Wealth on Individual Gross Labor Earnings

\begin{tabular}{|c|c|c|c|c|c|c|}
\hline & $t=1$ & $t=2$ & $\begin{array}{c}\text { 3-year } \\
\text { total }\end{array}$ & $\begin{array}{c}\text { 5-year } \\
\text { total }\end{array}$ & $\begin{array}{c}\text { 10-year } \\
\text { total }\end{array}$ & $\begin{array}{c}\text { Event study } \\
\text { estimate } t=1-5\end{array}$ \\
\hline & (1) & (2) & $(3)$ & (4) & (5) & (6) \\
\hline Prize Amount (SEK/100) & -1.152 & -1.177 & -3.219 & -4.681 & -8.033 & -1.068 \\
\hline SE & $(0.153)$ & $(0.191)$ & $(0.517)$ & $(0.917)$ & $(1.961)$ & $(0.149)$ \\
\hline$p$ & {$[<0.001]$} & {$[<0.001]$} & {$[<0.001]$} & {$[<0.001]$} & {$[<0.001]$} & {$[<0.001]$} \\
\hline$N$ & 199,168 & 211,555 & 193,312 & 186,819 & 173,129 & 249,278 \\
\hline
\end{tabular}

Notes: This table reports results of estimating equation (2) in the pooled lottery sample with gross labor earnings as the dependent variable. The prize amount is scaled so that a coefficient of 1.00 implies a 1 SEK increase in earnings per 100 SEK won. 
Table 3. Effect of Wealth on Different Measures of Individual Earnings

\begin{tabular}{|c|c|c|c|c|c|c|c|c|c|}
\hline \multirow{3}{*}{ Taxes } & \multicolumn{2}{|c|}{ Labor Earnings } & \multirow{2}{*}{$\begin{array}{c}\text { Wage } \\
\text { Earnings } \\
\text { Pre-tax }\end{array}$} & \multirow{2}{*}{$\begin{array}{c}\begin{array}{c}\text { Self-employment } \\
\text { Income }\end{array} \\
\text { Pre-tax }\end{array}$} & \multirow{2}{*}{$\begin{array}{c}\text { Unemployment } \\
\text { Benefits } \\
\text { Pre-tax }\end{array}$} & \multirow{2}{*}{$\begin{array}{c}\text { Pensions } \\
\text { Pre-tax }\end{array}$} & \multicolumn{3}{|c|}{ Taxable earnings } \\
\hline & Pre-tax & $\begin{array}{c}\text { Pre-tax } \\
\text { incl. SSC }\end{array}$ & & & & & Pre-tax & Post-tax & $\begin{array}{l}\text { Post-tax incl. } \\
\text { SSC benefits }\end{array}$ \\
\hline & (1) & $(2)$ & (3) & (4) & (5) & (6) & (7) & (8) & $(9)$ \\
\hline Prize Amount (SEK/100) & -1.068 & -1.412 & -0.967 & -0.142 & 0.035 & 0.157 & -0.900 & -0.580 & -0.624 \\
\hline SE & $(0.149)$ & $(0.199)$ & $(0.151)$ & $(0.036)$ & -0.026 & -0.085 & -0.131 & -0.081 & -0.084 \\
\hline$p$ & {$[<0.001]$} & {$[<0.001]$} & {$[<0.001]$} & {$[<0.001]$} & [0.177] & {$[0.064]$} & {$[<0.001]$} & {$[<0.001]$} & {$[<0.001]$} \\
\hline$N$ & 249,278 & 247,847 & 247,915 & 248,058 & 248,058 & 248,058 & 249,278 & 247,847 & 247,847 \\
\hline
\end{tabular}

Notes: This table reports event-study estimates obtained by estimating equation (2) in the pooled lottery sample with different earnings measures as the dependent variable. The earnings measure in column (2) includes SSC paid by the employer and the column (9) earnings measure includes the implicit employee benefit of SSC. Labor earnings in column (1) and (2) includes wage earnings and selfemployment income used in columns (3) and (4). Taxable earnings in columns (7) to (9) includes labor earnings (column 1), unemployment benefits (column 5) and pension income (column 6). The variables are scaled so that a coefficient of 1.00 implies a 1 SEK increase in earnings per 100 SEK won.

Table 4. Margins of Adjustment

\begin{tabular}{|c|c|c|c|c|c|c|}
\hline & \multicolumn{4}{|c|}{ Extensive Margin (> 25K SEK) } & \multirow[b]{2}{*}{$\begin{array}{c}\text { Hours } \\
\text { (Percent of } \\
\text { Full-time) } \\
(5)\end{array}$} & \multirow[b]{2}{*}{$\begin{array}{c}\text { Pre-tax } \\
\text { Monthly } \\
\text { Wages } \\
(6) \\
\end{array}$} \\
\hline & $\begin{array}{c}\text { Labor } \\
\text { Earnings } \\
(1) \\
\end{array}$ & $\begin{array}{c}\text { Wage } \\
\text { Earnings } \\
(2)\end{array}$ & $\begin{array}{c}\begin{array}{c}\text { Self- } \\
\text { employment }\end{array} \\
(3) \\
\end{array}$ & $\begin{array}{c}\text { Pension } \\
\text { Income } \\
(\geq \text { Age 50) } \\
(4)\end{array}$ & & \\
\hline Prize Amount & -2.067 & -2.244 & -0.623 & 0.458 & -3.109 & -0.158 \\
\hline SE & $(0.449)$ & $(0.475)$ & $(0.253)$ & $(0.507)$ & $(0.616)$ & $(0.085)$ \\
\hline$p$ & {$[<0.001]$} & {$[<0.001]$} & {$[0.014]$} & [0.366] & {$[<0.001]$} & [0.063] \\
\hline Proportion/mean & $77.3 \%$ & $71.0 \%$ & $5.4 \%$ & $36.4 \%$ & $81.6 \%$ & 22,973 \\
\hline$N$ & 249,278 & 247,915 & 248,058 & 130,848 & 110,080 & 110,080 \\
\hline
\end{tabular}

Notes: This table reports event-study estimates obtained by estimating equation (2) in the pooled lottery sample. The variables in columns (1) to (5) are scaled so that a coefficient of 1.00 implies a 1 percentage point increase in participation or fraction of full-time worked per million SEK won, whereas the prize amount is scaled by 1000 SEK in column (6). 
Table 5. Simulation-based Estimates of Model Parameters

\begin{tabular}{|c|c|c|c|c|}
\hline \multicolumn{2}{|c|}{ Panel A: Minimum-distance Estimates } & \multicolumn{3}{|c|}{ Panel B: Reduced-form and Model-based Moments } \\
\hline & $\begin{array}{l}\text { Minimum-distance } \\
\text { estimates }\end{array}$ & & Reduced-form & Model-based \\
\hline$\beta / \mathrm{SE}$ & $0.855 /(0.010)$ & 100K SEK Prize & -3.12 & -2.95 \\
\hline$\delta / \mathrm{SE}$ & $0.010 /(0.005)$ & 1M SEK Prize & -2.99 & -2.94 \\
\hline \multirow[t]{2}{*}{$\gamma_{h} / \mathrm{SE}$} & 1852 / (39.7) & Below median earnings & -2.36 & -2.99 \\
\hline & & Above median earnings & -2.66 & -2.91 \\
\hline \multirow{3}{*}{$\begin{array}{l}\text { Goodness-of-fit, } \chi^{2}(8) \\
p \text {-value }\end{array}$} & 3.428 & Age 21-34 & -3.06 & -1.71 \\
\hline & [0.095] & Age $35-54$ & -3.13 & -3.41 \\
\hline & & Age 55-64 & -1.06 & -2.66 \\
\hline
\end{tabular}

Notes: This table reports results of estimating the dynamic model via indirect inference, with asymptotic standard errors in parentheses. The goodness-of-fit test uses the minimized value of weighted minimum distance procedure, based on 11 moments and 3 parameters. The reduced form and model-based moments in Panel B shows the effect on total five-year after-tax earnings scaled in units of 100 SEK. The non-linear moments in the first two rows compares a lottery win of $100 \mathrm{~K}$ and $1 \mathrm{M}$ using the reduced-form results from a quadratic model.

Table 6. Implied Labor Supply Elasticities from Simulated Model

Panel A: Implied Lifetime Wealth Effects at Various Ages

\begin{tabular}{cccc} 
Age at Win & $\begin{array}{c}\text { Implied Lifetime } \\
\text { Wealth Effect } \\
(1)\end{array}$ & $\begin{array}{c}\text { Cumulative Wealth Effect } \\
\text { Over First 10 Years } \\
(2)\end{array}$ & $\begin{array}{c}\text { Effect Over First 10 Years } \\
\text { as Share of Lifetime Effect } \\
(3)\end{array}$ \\
\hline 20 & -0.186 & -0.031 & $16.7 \%$ \\
25 & -0.172 & -0.032 & $18.7 \%$ \\
30 & -0.159 & -0.035 & $22.2 \%$ \\
35 & -0.145 & -0.041 & $28.4 \%$ \\
40 & -0.129 & -0.049 & $38.3 \%$ \\
45 & -0.114 & -0.056 & $49.0 \%$ \\
50 & -0.107 & -0.078 & $72.9 \%$ \\
55 & -0.074 & -0.074 & $100.0 \%$ \\
60 & -0.046 & -0.046 & $100.0 \%$
\end{tabular}

Panel B: Implied Labor Supply Elasticities

(Win at Age 50, Retire at Age 65, Die at Age 80)

(1) Effect of lottery prize on total labor earnings over remaining working

(1) life (Implied Lifetime Wealth Effect)

$-0.107$

Effect of permanent change in wages on total hours worked

(2) (Uncompensated (Marshallian) Elasticity) 0.001

(3) Effect of transitory change in wages on hours worked
(Intertemporal Frisch Elasticity)

(4) Implied Compensated (Hicksian) Labor Supply Elasticity (from (1)
and (2) through Slutsky equation)

Notes: This table reports key labor supply elasticities implied from the model using the parameters reported in Table 5. Panel A reports elasticities at different ages. Each row computes the lifetime wealth effect and the wealth effect over the first 10 years. Row (1) in Panel B reports the effect of a lottery prize on total labor earnings (i.e., sum of dy/dL across all remaining working years, as implied by model), row (2) reports the implied effect of a permanent increase of wages on total hours worked (summed up across all remaining working years), row (3) reports the Frisch elasticity (i.e., effect of a transitory change in wages on hours worked), and row (4) shows the implied Hicksian elasticity from the Slutksy equation. 
Table 7. Effect of Wealth on Household Labor Earnings

\begin{tabular}{|c|c|c|c|c|}
\hline & \multicolumn{4}{|c|}{ Panel A: Married Winners } \\
\hline & $\begin{array}{c}\text { Household } \\
\text { (1) }\end{array}$ & $\begin{array}{c}\text { Winner } \\
(2)\end{array}$ & $\begin{array}{c}\text { Spouse } \\
(3)\end{array}$ & $\begin{array}{c}\text { Difference } \\
(4)\end{array}$ \\
\hline Prize Amount (SEK/100) & -1.439 & -0.981 & -0.458 & -0.522 \\
\hline SE & $(0.298)$ & $(0.200)$ & $(0.206)$ & $(0.276)$ \\
\hline$p$ & {$[<0.001]$} & {$[<0.001]$} & {$[0.026]$} & [0.059] \\
\hline \multirow[t]{3}{*}{$N$} & 144,979 & 144,979 & 144,979 & 144,979 \\
\hline & \multicolumn{2}{|c|}{$\underline{\text { Panel B: Unmarried Winners }}$} & \multicolumn{2}{|c|}{$\underline{\text { Panel C: Total Sample }}$} \\
\hline & $\begin{array}{c}\text { Household } \\
\text { (5) }\end{array}$ & $\begin{array}{c}\text { Winner } \\
(6)\end{array}$ & $\begin{array}{c}\text { Household } \\
\text { (7) }\end{array}$ & $\begin{array}{c}\text { Winner } \\
(8)\end{array}$ \\
\hline Prize Amount (SEK/100) & -1.259 & -1.259 & -1.324 & -1.068 \\
\hline SE & $(0.229)$ & $(0.229)$ & $(0.193)$ & $(0.149)$ \\
\hline$p$ & {$[<0.001]$} & {$[<0.001]$} & {$[<0.001]$} & {$[<0.001]$} \\
\hline$N$ & 101,473 & 101,473 & 249,278 & 249,278 \\
\hline
\end{tabular}

Notes: This table reports event-study estimates obtained by estimating equation (2) on winners, winners' spouses, and at the household level for different subsamples. Panel A includes all winners that were married the year before the lottery event, Panel B includes those that were unmarried, and Panel C includes both married and unmarried winners. The prize amount is scaled so that a coefficient of 1.00 implies a 1 SEK increase in earnings per 100 SEK won. The estimates in Panel A includes baseline controls for the winner's spouse. 